\title{
Osmanlı'da Gıda Güvenliği: Halk Sağlığı ve Uluslararası Ticaret Kıskacında Mahlût Zeytinyağları Meselesi
}

Oya Gözel-Durmaz*

Food Safety in the Ottoman Empire: The Problem of Adulterated Olive Oil in the Context of Public Health and International Trade

Abstract $\square$ Subjects relating to public health turned into a significant policy-making issue in the $19^{\text {th }}$ century, which is why governments took various measures to cope with public health matters. Food safety was considered a major component of the public health policies. An important point of contention became food adulteration. Due to the increase of commodity circulation throughout the world in the nineteenth century this emerged as a serious problem. By the middle of the 19th century, the Ottoman Empire was also incorporated into the capitalist world economy, which inevitably led to a high level of commodity flow into the domestic market. In the given circumstances, also the Ottoman authorities had to take measures against food adulteration. However, some of these measure impeded with the free trade agreements signed in this period which resulted in the involvement of foreign embassies. This article will examine the preoccupation of the authorities with food safety by delineating adulterated olive oil in the Ottoman Empire.

Keywords: Public Health, Food Safety, Food Adulteration, Olive Oil, Cottonseed Oil

\section{Giriş}

19. yüzyıl öncesi gıda tedariki doğal şartlara bağlı olduğundan öngörülemez bir durumdaydı. Bu nedenle de Avrupa'da birbirini takip eden iaşe sorunları yaşanmaktaydı. 19. yüzyıla geldiğimizde ise bölgesel kıtlıklar dışında Avrupa'da kıta çapında bir gıda sorunu kalmamıştı. 1790’lardan başlayarak 1815 yılına kadar devam eden uzun savaş dönemi, gıda sorununun ortadan kalkmasında etkili olmuştu. Bu savaş

* Kocaeli Üniversitesi.

Makalenin gelişimindeki değerli katkıları ve yorumları için Orkun Saip Durmaz’a ve Osmanlı Araştırmaları dergisi hakemlerine teşekkür ederim 
süreci boyunca yüz binlerce kişiden oluşan orduların ve donanmaların besin ihtiyacı, gıda endüstrilerinin gelişimini adeta zorunlu kılıyordu. Dahası, 19. yüzyılda Avrupa’da yaşanan büyük nüfus artışı, endüstrileşme ve şehirleşme giderek daha fazla sayıda insanın yiyecek konusunda kendi kendine yeter konumdan uzaklaşması ve piyasaya bağımlılığının artması anlamına geliyordu. Gıda talebi artarken, yeni tarım teknikleri sayesinde tarımsal üretimde de önemli artışlar yaşanıyordu. Gemilere ek olarak, demiryolu gibi ulaşımda devrim yaratan araçların kullanımı ise gıdanın dünya çapında dolaşımı ve erişilebilirliğine katkıda bulunuyordu. ${ }^{1}$

Gıda talebinin arttığı ve gıda ürünlerinin giderek daha fazla metalaştığı bu süreç, gıdada sahtekârlık gibi önemli bir meseleyi de devletlerin ve kamuoyunun gündemine getirmişti. Her ne kadar gıda sahtekârlığının tarihi çok daha eskilere dayanıyor olsa da, 19. yüzyıldaki bilimsel gelişmeler, özellikle de kimya alanındaki ilerlemeler, "tağşşş" sorununu derinleştirmişti. Uluslararası ticaret hacminin hızla genişlediği bu dönemde üreticiler, yoğun rekabet ortamında ayakta kalabilmek için ürünlerini olabildiğince ucuza mal etmeye çalışıyorlardı. Rekabet üstünlüğü sağlamaya çalışan üreticilerin başvurduğu en önemli araçlardan biri ise, dönemin bilimsel gelişmelerinden de yararlanarak, gıdayı tağşş̧ etmekti. ${ }^{3}$

Tağşişteki artış, Batı kamuoyunda yankı bulmuş; bu konuda oluşan hassasiyet devletleri gıda sahtekârlığına karşı birtakım önlemler almaya itmiştir. 19. yüzyılın ikinci yarısından itibaren, halkı tağşiş karşısında korumayı hedefleyen yasal düzenlemeler de böylece gündeme gelmiştir. ${ }^{4}$ İlgili yasal düzenlemelerin hayata

1 Derek J. Oddy, “Introduction,” Derek J. Oddy, Alain Drouard (ed.), The Food Industries of Europe in the Nineteenth and Twentieth Centuries (New York: Routledge, 2016), s. 3-7.

2 Tağşiş, bir maddenin içine başka bir madde karıştırarak saflığını bozma anlamına gelmektedir.

3 Peter Scholliers, tarihçilerin 19. yüzyılı gıda sahtekârlığının "altın çağı” olarak değerlendirdiklerini belirtir. Peter Scholliers, "Food Fraud and the Big City: Brussels" Response to Food Anxieties in the 19th Century," Peter Atkins, Peter Lummel, Derek J. Oddy (ed.), Food and the City in Europe Since 1800 (Aldershot: Ashgate Publishing, 2007), s. 77, 80, 86; Jessie Shillington, "History of National Pure Food and Drug Legislation in the United States to 1906" (Yayımlanmamış Master Tezi), University of Kansas, 1915, s. 9.

4 Ayrıntılı bilgi için bkz.: Report of the Commissioner of Internal Revenue for the Fiscal Year Ended June 30, 1888 (Washington: Government Printing Office, 1888), s. CLXXXV-CCX (https://babel.hathitrust.org/cgi/pt?id=njp.32101067873743; view=1up;seq=9;size=125) (Erişim 31 Ocak 2018); Adulteration of Food, Drink and Drugs (London: 1855); Edgar Richards, "Legislation of Food Adulteration," Science, 16/394 (Aug. 22, 1890), s. 101-104; Jim Phillips, Michael French, "Adulteration and Food Law, 1899-1939," Twentieth Century British History, 9/3 (1998), s. 350-369; Shillington, "History of National Pure Food and Drug Legislation in the United States to 1906," s. 4-12; Derek J. Oddy, "Food Quality in 
geçirilmesi ve gıda analizlerinin yapılabilmesi amacıyla çeşitli Avrupa şehirlerinde gelişkin kimya laboratuvarlarının kurulması da yine bu sürece tekabül etmektedir. Bu çerçevede ilk olarak 1856 yılında Brüksel'de bir belediye laboratuvarının kurulduğu görülmektedir. Bunu 1878 yılında Paris’te açlan belediye laboratuvarı izlemiş ve söz konusu laboratuvar, Fransảda gıda tağşş̧ine karşı analizlerin yapıldığı en önemli merkez haline gelmiştir. ${ }^{5}$

Gıda güvenliği konusunda oluşan hassasiyet ülkelerin iç meselesi olarak kalmamış, 1876 yılından itibaren düzenlenen Uluslararası Hijyen ve Demografi Kongrelerinde bu mevzu üzerine görüşler dile getirilmiştir. İlk olarak 1882 yılında Cenevre'de düzenlenen 4. Kongrede Fransız delegesi Profesör Brouardel, gıda tağşşisi yapanların bu işi ciddi bir kimya bilgisine ve maddi sermayeye dayanarak yaptıklarına dikkat çekmiş ve gıda ürünlerinin uluslararası ticarete tabi olduğu bir dönemde, bu sorunun devletlerce alınan münferit önlemlerle çözülemeyeceğini vurgulamıştır. Prof. Brouardel'in konuyu gündeme getirmesi ve uyarıları karşılık bulmuş; 1887 yılında Viyana'da düzenlenen Uluslararası Hijyen ve Demografi Kongresi'nde dağıtılan yirmi kitap ve broşür içinde gıda tağşişi meselesi de ele alınmıştır. Kongre raporlarında, üreticilerin yetkin kimyacılar kullanarak daha önce bilinmeyen farklı tağşiş yöntemlerini hayata geçirmeleri, gıda sahtekârlığında yeni dönemin bir özelliği olarak ifade edilmekteydi. Çeşitli ülkelerdeki kanun ve yönetmelikleri inceleyen Prof. Brouardel, tağşiş ile mücadele yönünde genel bir eğilim olduğunu tespit etmekle birlikte, ülkelerin mevzuatları arasında ciddi farklar olduğunu da belirtmiştir. Kongrede, uluslararası ticaret yapan ülkelerin gıda

London and the Rise of Public Analyst, 1870-1939," Peter Atkins, Peter Lummel, Derek J. Oddy (ed.), Food and the City in Europe Since 1800 (Aldershot: Ashgate Publishing, 2007), s. 91-98; Vera Hierholzer, “The 'War Against Food Adulteration': Municipal Food Monitoring and Citizen Self-Help Associaitions in Germany, 1870s-1880s," Peter Atkins, Peter Lummel, Derek J. Oddy (ed.), Food and the City in Europe Since 1800 (Aldershot: Ashgate Publishing, 2007), s. 117-128.

5 Ayrıntılı bilgi için bkz.: Peter Atkins, Alessandro Stanziani, "From Laboratory Expertise to Litigation: The Municipal Laboratory of Paris and the London Inland Revenue Laboratory, 1870-1914. A Comparative Analysis," Christelle Rabier (ed.), Fields of Expertise: a Comparative History of Expert Procedures in Paris and London, 1600 to Present (Newcastle upon Tyne: Cambridge Scholars Publishing, 2007), s. 317-339; Alessandro Stanziani, "Municipal Laboratories and the Analysis of Foodstuffs in France under the Third Republic: A Case Study of the Paris Municipal Laboratory, 1878-1907," Peter Atkins, Peter Lummel, Derek J. Oddy (ed.), Food and the City in Europe Since 1800 (Aldershot: Ashgate Publishing, 2007), s. 105-115; Oddy, "Food Quality in London and the Rise of Public Analyst, 18701939," s. 92-94; Scholliers, "Food Fraud and the Big City: Brussels," s. 77. 
güvenliği konusunda başka ülkelerdeki yasal düzenlemelere kayıtsız kalamayacağının da altı çizilmiştir. İki yıl sonra 1889'da Paris'te düzenlenen 8. Uluslararası Hijyen ve Demografi Kongresi'nde de önemini koruyan gıda tağşişi meselesi, kongrenin sekiz seksiyonundan biri olmuştur. ${ }^{6}$

Özellikle 19. yüzyılın ikinci yarısından itibaren gelişmiş Batı ülkelerinin gündemini işgal eden gıda güvenliği, Osmanlı Devleti’nin de çözüm getirmeye çalıştı̆̆ bir mesele haline gelmiştir. 1879 yılında Şehremaneti'ndeki gıda teftiş servisinin başına geçen Bonkowski Paşa’nın piyasadan alınan numuneler üzerinde yaptığı kimyasal analizler de bu durumu doğrular nitelikteydi. Yapılan tahliller sonucu, analiz edilen ürünlerin çoğunun mağşuş (saf olmayan) maddeler olduğu ortaya çıkmıştır. Bonkowski Paşa'ya göre yabancı devletlerle ticari ilişkilerin arttı̆̆g 1850'lerden itibaren, Osmanlı Devleti'nde tağşiş vakaları artmıştı. Tağşiş edilen ürünler arasında un, süt ve süt ürünleri, çeşitli yağlar, alkol, şarap, baharat, konserveler ve çay başta gelmekteydi.' Osmanlı Ceza Kanunu'nun 194. maddesi de bu soruna değinerek, tağşişe bulaşarak gıda maddeleri, içecekler ve ilaçların esas bileşimini sağlığa zarar verecek şekilde değiştirenler hakkında cezalar öngörmüştü. ${ }^{8}$

1885 yılında oluşturulan Hıfzıssıhha-i Umumiye Komisyonu'nun görevleri arasında gıda tağşsişine karşı mücadelenin temel bir unsur olarak yer alması, gıda sahtekârlığının kamu sağlığını tehdit eder bir mesele haline geldiğini de göstermektedir. ${ }^{9}$ Yenilip içilecek şeyler ve ilaç gibi maddelerin İstanbul'daki belediye daireleri ve gümrüklerce denetlenmesini öngören söz konusu düzenleme uyarınca,

6 Lancet Reports of the International Congresses of Hygiene and Demography held from 1876 to 1889 (London: Ballantyne, Hanson and Co., 1891), s. 8-9, 28, 50, 57. Osmanlı Devleti de bahsi geçen kongrelere temsilci göndermiştir.

7 Feza Günergun, "XIX. Yüzyılın İkinci Yarısında Osmanlı Kimyager-Eczacı Bonkowski Paşa (1841-1905)," I. Türk Tip Tarihi Kongresi Kongreye Sunulan Bildiriler (Ankara: TTK, 1992), s. 245-247; Feza Günergun, "Chemical Laboratories in Nineteenth-Century Istanbul: A CaseStudy on the Laboratory of the Hamidiye Etfal Children's Hospital,” Marta C. Lourenço, Ana Carneiro (ed.), Spaces and Collections in the History of Science The Laboratorio Chimico Overture (Museum of Science of the University of Lisbon, 2009), s. 91-92.

8 Osman Nuri Ergin, Mecelle-i Umur-ı Belediyye, cilt 6 (İstanbul: İstanbul Büyükşehir Belediyesi Kültür İşleri Daire Başkanlığı Yayınları, 1995), s. 3622-3623; Nuran Yıldırım, "Osmanlı Devleti'nde Gıda Kontrolüne Bakış," 14. Yüzyıldan Cumhuriyet’e HastalıklarHastaneler-Kurumlar Sağlık Taribi Yazıları I (İstanbul: Tarih Vakfı Yurt Yayınları, 2014), s. 61.

9 "1. Madde: Mekulat ve meşrubat ve ecza-yı tıbbiye vesaireyi teftiş ve muayene ile muzır-1 sıhhat olanların füruhtunu menettirmek ve indel-teftiş sıhhat-i umumiyenin istilzam ettiği mevaddı icra icabı zımnında merciine bildirmek üzere Hıfzıssıhha-i Umumiye Teftiş 
özellikle gümrüklerde aktif bir çalışma yürütülmüş; gümrüğe gelen gıda, ilaç ve çeşitli diğer ürünler, gümrük laboratuvarlarında analiz edilmiştir. Gümrüklerde kurulmuş olan laboratuvarların yetersiz kaldığı durumlarda ya da gümrük ile tüccarlar arasında yaşanan sorunlardaysa Mekteb-i Tibbiye-i Şahane’nin kimya laboratuvarı öne çımış ve bu laboratuvar o dönemde referans laboratuvar olarak hizmet vermiştir. ${ }^{10}$ Tibbiye öğrencilerinden Tevfik Sağlam da anılarında okul laboratuvarının bu konumundan bahsetmektedir:

Tibbiye Kimyahanesi önemli bir müessese idi. Analiz işlemlerinde son sözü söyleyen bir makam. Burada analizler ve kontroller büyük bir itina ile yapılırdı ve neticelerine herkes inanırdı. Gümrük kimyahanesiyle tüccar arasında çıkan ihtilaflar orada halledilirdi. Kimyahanenin analizine inanmayan tüccar tarafından Paris Belediye Kimyahanesinde yaptırılan analizlerin sonuçları en küçük kesirlerine varıncaya kadar kimyahanemizde alınan neticelere uyardı. ${ }^{11}$

Mekteb-i Tibbiye-i Şahane laboratuvarına bu konumu dolayısıyla yoğun başvuru olduğunu, 1870 yılında ilgili laboratuvarda gerçekleştirilecek analizler hakkında bir fiyat listesi yayınlanmasından anlayabiliyoruz. Bahsi geçen fiyat listesine göre yapılan tahliller başlıca altı başlık altında sıralanabilir: Adli tıp ile ilgili analizler, ilaç analizleri, piyasada bulunan çeşitli kimyasal maddelerin analizleri, besin maddesi analizleri, su ve madeni para analizleri. ${ }^{12}$ Resmi kurum laboratuvarlarının yanı sıra özel tıbbi laboratuvarlarda da bazı gıda maddelerinin analizleri yapılmaktayd.$^{13}$

Komisyonu namıyla bir heyet-i teftişiyye teşkil olunmuştur.” Ergin, Mecelle-i Umur-ı Belediyye, cilt 6, s. 3090.

10 Günergun, "Kimyager-Eczacı Bonkowski Paşa (1841-1905),” s. 245-247; Günergun, "Chemical Laboratories," s. 91-92; Eyüp Talha Kocacık, Afife Mat, "İstanbul'da Zehirler ve Zehirlenme Vakaları (1846-1917),” Osmanl Bilimi Araștırmalar, XV/2 (2014), s. 25, 34.

11 Tevfik Sağlam, Nasıl Okudum (İstanbul: İstanbul Matbaası, 1981), s. 64.

12 Emre Dölen, “1870’li Yıllarda Mekteb-i Tibbiye Laboratuvarında Yapılan Analiz ve İncelemeler,” Marmara Üniversitesi Eczacılık Dergisi, 2 (1992), s. 148-154. Mekteb-i Tıbbiye-i Şahane dâhilinde ilk kimya laboratuvarı 1844 yılında kurulmuş, ancak söz konusu laboratuvar okulda 1848 yılında çıkan yangın dolayısıyla yok olmuştur. 18781903 arasında okulun yeni binasında da gelişkin bir kimyahanenin işler durumda olduğu bilinmektedir. Mutahhar Yenson, "19. Yüzyıl Tipsal Kimya Laboratuarcılığımızın Tıp Tarihimiz Bakımından Önemi,” I. Türk Tip Tarihi Kongresi Kongreye Sunulan Bildiriler (Ankara: TTK, 1992), s. 137.

13 Nuran Yıldırım, "İstanbul Eczanelerinde Hasta Muayenesi ve Tibbi Tahlil Laboratuvarları," Yeni Tip Tarihi Araştırmaları, 2-3 (1996/97), s. 71-97; Günergun, "Kimyager-Eczac1 Bonkowski Paşa (1841-1905),” s. 247. 
Gerek gümrüklerde gerekse Mekteb-i Tibbiye-i Şahane laboratuvarlarında yapılan analizler neticesinde insan sağlığına zararlı olduğu tespit edilen mağşuş ve mahlût (karışı) ürünlerin ülkeye girişine ise Osmanlı Devleti'nce müsaade edilmemekteydi. ${ }^{14}$ Ancak gıda güvenliği ve halk sağlığı adına alınan bu kararların uygulanması, Osmanlı Devleti'nin içinde bulunduğu siyasi ve iktisadi şartlar dolayısıyla çok kolay olmamıştır. Gıda tağşişine karşı mücadele etmek isteyen Osmanlı Devleti’nin ithal edilen kimi ürünlere karşı aldığı tedbirler veya gümrüklerde yaptığ 1 kontroller, yabancı tüccarların ve onları temsilen elçiliklerin veya konsoloslukların konuya müdahil olmasına yol açmıştır. Bu süreçte, Osmanlı Devleti gıda sahtekârlığına karşı mücadele etmeye çalışırken, Batılı devletler serbest ticaretin ihlal edildiği iddiasıyla Osmanlı Devleti’ni diplomatik baskı altına almışlar ve ticari ilişkilerin kontrollerden azade şekilde sürdürülmesi için uğraş vermişlerdir. Dolayısıyla, tağşsiş sorunu aynı zamanda Osmanlı Devleti ile Batılı devletler arasında yaşanan bir mücadeleye de konu teşkil etmiştir. Bu çalışma, o mücadeleyi mahlût zeytinyağları üzerinden analiz etmeyi hedeflemektedir. Bu çerçevede de temel savı, hıfzıssıhha kapsamında gıda güvenliğini sağlamak için alınan önlemler ve geliştirilen politikaların yalnızca nüfusun sağlığını koruma hedefi kapsamında değil uluslararası politika ve ekonomik faktörler de dikkate alınarak değerlendirilmesi gerektiğidir. Çalışmada bu kapsamda, Osmanlı Devleti'nin zeytinyağı tağşişini engellemek için aldığı önlemler ile bu önlemlere karşı yabancı devletlerin takındığı tutumlar incelenecek ve gıda güvenliği, sadece halk sağlığını ilgilendiren bir mevzu olmanın ötesinde, 19. yüzyılın iktisadi ve diplomatik ilişkilerinde yansımasını bulan bir mücadele alanı olarak analiz edilecektir.

Literatüre baktığımızda kamu sağlığı çerçevesinde gıda güvenliği meselesinin Osmanlı tarih yazınında ihmal edilmiş bir konu olarak kaldığı görülmektedir. Osmanlı gıda tarihi ile ilgili çalışmalar ağırlıklı olarak iaşe sistemi, gıda üretimi ve ticareti ile tüketim alışkanlıkları mevzularına odaklanırken; ${ }^{15}$ özellikle gıda dolaşımının dünya çapında muazzam boyutlara ulaştığı ve gıda sahtekârlığının insan

14 Ergin, Mecelle-i Umur-ı Belediyye, cilt 6, s. 3090. "10. Madde: Gümrüklere vürud eden edviye-i hususiye ve istihzarat-1 kimyeviye ve ispenciyariye ve her nev’ meşrubat ve mekulatı müfettişler muayene ederek içlerinde tenavül ve istimalinde sıhhati ihlal edecek mağşuş ve mahlût mevad zuhurunda imrarına müsaade edilmeyip zabt ve tevkif olunmak üzere ait olduğu gümrük nezaretine ba-raporto beyan-1 hal edecek ve Tibbiye Nezareti'ne dahi malumat verecektir."

15 Ayrıntılı bilgi için bkz., Özge Samancı, “Avrupa'da ve Türkiye’de Yemek Tarihçiliğine Kısa Bir Bakış," Ayşegül Avcı, Seda Erkoç, Elvin Otman (haz.), Yemekte Tarih Var Yemek Kültürü ve Tarihçiliği (İstanbul: Tarih Vakfı Yurt Yayınları, 2012), s. 27-40. 
sağlığı açısından ciddi bir mesele haline geldiği 19. yüzyıl özelinde Osmanlı'da gıda güvenliği konusunu inceleyen çok az sayıda çalışma yapılmıştır. Bu kapsamda öncelikle Nuran Yıldırım’ın “Osmanlı Devleti'nde Gıda Kontrolüne Bakış" adlı makalesinden bahsetmek gerekir. Gıda güvenliğini sağlamak adına Osmanlı Devleti’nin uygulamaya koyduğu yasal düzenlemeleri inceleyen Yıldırım'ın çalışması konuyu doğrudan irdelemesi açısından önemlidir. Bunun dışında Layla J. Aksakal'ın da 19. yüzyılda Osmanlı Devleti'nde gıda ve ilaç kontrollerine dair mevzuatı incelediği bir çalışması bulunmaktadır. ${ }^{16}$ Gıda tağşişi konusu ise Osmanlı sancak ve vilayetlerinin ekonomik durumunu analiz eden çalışmalar ile belirli gıda maddelerinin Osmanlı'daki üretimi ve ticareti üzerine odaklanan çalışmalarda bir alt başlık olarak kendine yer bulabilmiştir. ${ }^{17}$ Bunların yanında, yazında ıtriyat ve ilaç tağşişi gibi konuları ele alan çalışmalar da, sayıları az olmakla birlikte, bulunmaktadır. ${ }^{18}$

\section{Mahlût Zeytinyağları Meselesi}

Zeytinyağı 19. yüzyılda endüstride yaşanan gelişmelerden doğrudan etkilenen ürünlerden biridir. Öncelikle şunu belirtmek gerekir ki, bugün zeytinyağını büyük ölçüde yemeklik bir ürün olarak düşünmemize karşın, 19. yüzyıl ortalarında zeytinyağı gıda dışı alanlarda da kullanılan bir üründü. Gelişmiş ülkeler, sanayide makine, tekstilde ise yün yağlamak amacıyla; bunun yanında sabun imalatında ve

16 Yıldırım, “Osmanlı Devleti’nde Gıda Kontrolüne Bakış," s. 54-69; Layla J. Aksakal, "The Sick Man and His Medicine: Public Health Reform in the Ottoman Empire and Egypt" (2003 Third Year Paper, Harvard Law School, 26 April 2003) (Erişim 2 Şubat 2019). Osmanlı dönemiyle alakalı olmamakla birlikte Abdülhalik Bakır'ın Ortaçăg İslam Dünyasında Itriyat, Gıda, İlaç Üretimi ve Tăgssişi (Ankara: Bizim Büro, 2000) kitabına da değinmek gerekir.

17 Zeytinyağı özelinde baktığımızda Faruk Doğan’’n Osmanlı Devleti’nde zeytinyağı üzerine tez çalışmasında zeytinyağının kalitesini düşüren etkenlerden biri olarak tağşiş meselesi irdelenmiştir: Faruk Doğan, “Osmanlı Devleti’nde Zeytinyağı (1800-1920)” (Yayımlanmamış Doktora Tezi), Marmara Üniversitesi, 2007. Yine Metin Ünver’in Midilli Adası'nın sosyo-ekonomik yapısı ile ilgili doktora çalışmasında da sabun ve zeytinyağı üretiminde karşılaşılan ciddi sorunlardan biri olarak tağşiş incelenmiştir: Metin Ünver, "Midilli Adası'nın İdari ve Sosyo-Ekonomik Yapısı (1876-1914)” (Yayımlanmamış Doktora Tezi), İstanbul Üniversitesi, 2012.

18 Bu kapsamda şu makalelere bakılabilir: Kerim Sarıçelik “Osmanlı Dönemi’nde Isparta ve Burdur Sancaklarında Gülcülük ve 1913 Tarihli Gül Yağlarının Men-i Tağşişi Talimatnamesi," SDÜ Fen Edebiyat Fakültesi Sosyal Bilimler Dergisi, 38 (Ağustos, 2016), s. 37-50; Feza Günergun, Şeref Etker, "From Quinaquina to 'Quinine Law': A Bitter Chapter in the Westernization of Turkish Medicine," Osmanlı Bilimi Araştırmaları, XIV/2 (2013), s. 41-68. 
aydınlatmada yemeklik olmayan zeytinyağı kullanmaktaydı. Ancak daha ucuz ve verimli tohum yağları, hayvan yağları ve mineral yağlar, zeytinyağının endüstride uygulandığı alanlarda giderek daha fazla kullanılmışlar ve zamanla onun yerini almışlardır. Yemeklik olmayan zeytinyağı artık endüstride talep edilmeyen bir ürün haline gelince, zeytinyağ 1 üreticileri ve tüccarları yemeklik zeytinyağı piyasasını genişletme çabalarına ağırlık vermiş, bu çerçevede ürün kalitesini arttıracak teknik değişimleri hayata geçirmiş̧lerdir. Bu süreç sonucunda, zeytinyağı üretiminde yüzyıllardan beri süren klasik üretim teknikleri yerine mekanizasyona geçilmiş; kırma, ezme, arıtma, depolama ve ambalajlama gibi üretim aşamalarında ciddi gelişmeler yaşanmıştır. 19. yüzyılın son yıllarında Akdeniz havzasında büyük ölçekli ve yüksek kalitede endüstriyel yemeklik zeytinyağı üretimi, bu gelişmeler sonucu söz konusu olmuştur. ${ }^{19}$

Sanayide zeytinyağına olan talebin azalmasının ve daha ucuz yağların tercih edilir hale gelmesinin Osmanlı zeytinyağı ihracatını olumsuz etkilediği görülmektedir. ${ }^{20}$ Hangi zeytinyağ 1 tipinin üretiminde uzmanlaşıldığı, ihracat performansını etkileyen faktörlerin başında gelmekteydi. Endüstride kullanılmak için üretilen yağlar, düşük kaliteli ve ucuz iken; markalı yemeklik yağlar, kaliteli ve daha yüksek fiyatlı ürünlerdi. 1909-1913 verilerine göre Osmanlı'dan ihraç edilen zeytinyağlarının \%80 kadarı markasız yemeklik yağlar iken, \%20 kadarı endüstride kullanılan yağlardı. En çok kazanç getiren markalı yemeklik zeytinyağı ihracatının ise olmadığı anlaşılmaktadır. Bu rakamlar, Osmanlı üreticilerinin düşük kalite ve markasız zeytinyağı üretiminde uzmanlaştığını ortaya koymaktadır. ${ }^{21}$

Kaliteli ve piyasa değeri yüksek ürünler üretememesi nedeniyle sıkıntılı bir süreçten geçen Osmanlı zeytinyağı üreticilerinin ${ }^{22}$ karşı karşıya kaldığı bir diğer

19 Zeytinyağının üretim teknolojisinde 19. yüzyılın 2. yarısından itibaren yaşanan gelişmeler hakkında ayrıntılı bilgi için bkz.: Ramon Ramon-Muñoz, "Modernizing the Mediterranean Olive-Oil Industry, 1850s-1930s," Derek J. Oddy, Alain Drouard (ed.), The Food Industries of Europe in the Nineteenth and Twentieth Centuries (New York: Routledge, 2016), s. 71-75.

20 Zeytinyağı ihracatının 1878 ile 1913 yılları arasındaki değeri ve toplam ihracat içindeki payı için bkz.: Şevket Pamuk, 19. Yüzynlda Osmanlı Dı̧̧ Ticareti Tarihi İstatistikler Dizisi Cilt 1 (Ankara: T.C. Başbakanlık Devlet İstatistik Enstitüsü, 1995), s. 37-39; Vedat Eldem, Osmanlı Imparatorluğu’nun İktisadi Şartları Hakkında Bir Tetkik (Ankara: TTK, 1994), s. 33.

21 Ramon Ramon-Muñoz, "Specialization in the International Market for Olive Oil Before World War II,” Şevket Pamuk ve Jeffrey G. Williamson (ed.), The Mediterranean Response to Globalization before 1950 (London: Routledge, 2000), s. 161, 164, 171-173.

22 On dokuzuncu yüzyılda Osmanlı'da zeytinyağı üretimi dediğimizde her ne kadar üretim Osmanlı ülkesinde yapılsa da sermaye sahiplerinin yerel olmayabileceğini akılda tutmak 
sorun ise tağşişti. Zeytinyağı, hem halkın temel tüketim maddeleri içinde yer alması hem de uluslararası ticarette ağırlığı olan önemli bir endüstriyel meta olması itibariyle tağşiş edilen ürünler arasında ilk sıralarda yer almaktaydı ${ }^{23} 1885$ tarihli Hıfzıssıhha-i Umumiye Komisyonu Talimatı'nın 7. maddesinde yenilip, içilen şeylerin muayene ve teftiş edileceği belirtilirken, "sadeyağlar, iç yağları ve zeytinyağının" özellikle incelemeye tabi tutulacağının altı çizilmekteydi. ${ }^{24}$ Zeytinyağında tağşsiş, başta pamukyağı olmak üzere daha ucuz başka yağların zeytinyağıyla karıştıılması suretiyle yapılmaktayd.$^{25}$ Aslında Osmanlı Devleti’nde pamukyağı üretimi oldukça geç tarihlerde başlamış olduğu için ${ }^{26}$ zeytinyağına karıştırılan pamukyağlarının

gerekir. Kurmuş’un aktardığına göre Batı Anadolu ve Ege Adalarında zeytincilik önemli bir faaliyet olsa da bu ürün daha çok hammadde biçiminde satılmış ve mamul mal olarak, yani zeytinyağı olarak, ithal edilmiştir. Bu durum ancak 19. yüzyılın ikinci yarısında İngiliz tacirlerin bölgeye yatırım yapmalarının ardından değişmiştir. Ege kıyı şeridi boyunca yăg ve sabun üreten fabrikalar kuran İngilizler arasında en başarılısı ise Robert Hadkinson olmuştur. 1875 yılında Ayvalık’ta kurduğu tesis ile üretime başlayan Hadkinson, 1900 yılına gelindiğinde kurduğu 10'u zeytinyağı, 6'sı pamuk tohumu, 4’ü susam ve 2'si ayçiçeği yağı çıkaran 22 fabrika ile bu bölgenin en büyük yağ üreticisi haline gelmiştir. Orhan Kurmuş, Emperyalizmin Türkiye’ye Girişi (İstanbul: Yordam Kitap, 2007), s. 192-196. Hadkinson'un bu başarısında Midilli konsolos vekili Fredrik Hadkinson'un kardeşi olmasının da muhakkak bir payı vardı. Ünver, "Midilli Adası," s. 383.

23 Osmanlı Devleti'nde zeytinyağı üretimi ve ticaretinin 19. yüzyıldaki gelişimi hakkında ayrıntılı bilgi için bkz., Doğan, "Osmanlı Devleti'nde Zeytinyağı."

24 Ergin, Mecelle-i Umur-ı Belediyye, cilt 6, s. 3090.

25 Altı çizilmelidir ki zeytinyağı tağşişi sadece Osmanlı Devleti’nin uğraştığı bir problem değildi. Örneğin Amerika Birleşik Devletleri’nde de mahlût zeytinyağları 20. yüzyılın ilk yılları itibariyle kamuoyunun ve devlet yetkililerinin dikkatini çeken bir mesele haline gelmiştir. Birleşik Devletler, uluslararası alanda en önemli pamukyağı üreticileri arasında yer alırken, ülkede tüketilen zeytinyağlarının büyük kısmı Fransa ve İtalya'dan gelmekteydi. Bu dönemde, zeytinyağlarının büyük oranda pamukyağı ile karıştırılarak ülkeye ithal edildiği ve piyasada satıldığına dair söylentilerin etkisiyle, Amerikan Tarım Bakanlığı, sağlığa zararlı gıdaların ülkeye ithalini ve gıda ürünlerinin yanıltıcı şekilde markalanmasını yasaklayan federal yasalara dayanarak, gümrüğe gelen ve piyasada satılan zeytinyağlarının analizini yapmıştır. Bahsi geçen analizlerde, gümrüğe gelen zeytinyağlarının oldukça az bir kısmı mahlût çıarken (61 örnekten sadece 5’i), piyasada satılan yabancı etiketli zeytinyağlarının çoğunun pamukyağıyla tağşş̧ edildiği görülmüştür. Gümrük tahlilleri ile piyasada satılan ürünler arasındaki bu farklılı̆̆ın nedenine dair, yağların büyük ihtimalle limandan girişten sonra değiştirilip yeniden etiketlendikleri çıkarımında bulunulmuştur. Ayrıntılı bilgi için bkz.: L. M. Tolman, L. S. Munson, Olive Oil and Its Substitutes (Washington: Government Printing Office, 1903).

26 Kurmuş’un belirttiğine göre bu dalda da karşımıza Robert Hadkinson ismi çıkmaktadır. İlk pamukyağı fabrikasını 1886 'da Aydın'da kuran Hadkinson, modern üretim yöntemleri 
neredeyse tamamı yurtdışından ithal edilmekteydi. Saf pamukyağının bahsi geçen yıllarda hemen hiçbir Osmanlı sanayisinde kullanılmadığı göz önüne alındığında, ithal pamukyağlarının temel kullanım alanının -zeytinyağına olan benzerliği dolayısıyla- zeytinyağını tağşiş etmek olduğu Cemiyet-i Tıbbiye-i Mülkiye raporlarına da yansımıştı. Pamukyağı, zehirli bir madde olmamakla birlikte sindiriminin zor olmasından dolayı gıda maddesi olarak tüketimi tasvip edilmemekte, zeytinyağı derecesinde bir yağ olarak değerlendirilmemekteydi. Ancak zeytinyağına benzerliği nedeniyle, tüccarlar söz konusu yağları karıştırarak, pamukyağını zeytinyağı diye satmaktaydı. 15 Mart 1886 tarihli bir Cemiyet-i Tıbbiye-i Mülkiye kararnamesi, Heyet-i Teftişat-1 Sıhhiye'nin başkentte gerçekleştirdiği bir araştırmaya dayanarak durumun oldukça vahim bir hal aldığının altını çizmektedir. Değinilen araştırma sonuçlarına göre, İstanbul'da satılmakta olan zeytinyağlarının büyük kısmı pamukyağıyla karıştırılmıştı ve hatta satılan yağların birçoğunda pamukyağı oranı \%80'i bulmaktaydı. Oysaki Osmanlı kanunlarına göre bu tağşşş işlemleri, cezai müeyyidesi olan suçlardı. Cemiyet-i Tıbbiye-i Mülkiye kararnamesinde pamukyağı ithalinin esas nedeninin zeytinyağını tağşiş etmek olduğu belirtilirken, bu durumun halk sağlığını tehlikeye atmakla kalmayıp, Devlet-i Aliyye ticaretine de zarar verdiği vurgulanmıştı. Buradan hareketle de yağ tağşişi işine girişecekleri engelleyecek tedbirlerin alınması istenmişti. ${ }^{27}$

Cemiyet-i Tıbbiye-i Mülkiye'nin halk sağlığının korunması adına alınmasını tavsiye ettiği tedbirler gerçekten de uygulamaya konmuş, mahlût yağların ithaline mâni olmak için birtakım adımlar atılmışır. Bir taraftan gümrüklerde yapılan analizler sonucu mahlût yağların ülkeye girişi engellenirken, diğer taraftan ülke içinde ele geçirilen mahlût zeytinyağları müsadere edilmiş ve satışları yasaklanmıstır. ${ }^{28} 9$ Aralık 1886 tarihi itibariyle ilgili kararın uygulamaya konması için Dâhiliye Nezareti, Osmanlı’nın zeytinyağı üreten vilayetleri, Hüdavendigar, Suriye, Trablusgarp, Girit, Cezayir-i Bahr-i Sefid ve Karesi'den en halisinden zeytinyağı numuneleri talep etmiştir. Böylece mahalli zeytinyağlarının kimyevi değerlerini tespit etmek

ve makineleri kullanması sayesinde bu işten büyük kar elde etmiştir. İzmir'deki Samolda Pamukyağı Fabrikası da yine bir İngiliz yatırımıdır. 1910 yılında ise önemli bir pamuk üretim alanı olan Mersin çevresi, İngiliz yatırımcıların ilgisini çekmiş; şehirde Londra merkezli Mersin Yağ Fabrikası adlı bir şirket kurulmuştur. Yine Londra merkezli Osmanlı Yağ Şirketi de 1913 'te İzmir'de bir pamukyağı fabrikası kurmuştur. Kurmuş, Emperyalizmin Türkiye’ye Girişi, s. 193-197.

27 Başbakanlık Osmanlı Arşivi (BOA), HR.HMŞ.İŞO, 173/6; BOA, HR.HMŞ.İ̧̧O, 173/25

(Fransızcadan çeviren Utku Yasa).

28 BOA, HR.TH, 74/10 
isteyen Osmanlı Devleti, daha sonra yapılacak tahlillerde bu değerleri mukayese için kullanmak hedefindeydi. Yine Hariciye Nezareti'nden de benzeri bir talepte bulunulmuş; Devlet-i Aliyye şehbenderlerinin Osmanlı'ya zeytinyağı gönderen Yunanistan gibi yerlerden en halisinden zeytinyağı numuneleri göndermeleri istenmiştir. $^{29}$

Ancak pamukyağının zeytinyağına karıştırılmasının engellenmesi için alınan bu önlemler yalnızca dâhiliyeyi etkilememiş, uluslararası ticari etkileri dolayısıyla çeşitli ülke hariciyeleri de meseleye müdahil olmuştur. Bu kapsamda, özellikle Fransa’nın itirazları ön plana çıkmış; Fransız Elçiliği, gümrüklerde mahlût yağları alıkonulan Fransız tüccarlar adına Osmanlı nezdinde girişimlerde bulunarak, Osmanlı Devleti'ni aldığı kararlardan vazgeçirmeye çalışmıştır. İlgili itirazları tetikleyen başlıca olayın, Marsilyaadan ithal edilen zeytinyağlarının mahlût oldukları gerekçesiyle gümrükte alıkonulması ve Fransa'ya iade edilmemesi olduğu anlaşılmaktadır. Bu olay üzerine harekete geçen Fransız Elçiliği, pamukyağı veyahut başka yağlarla karıştırılan zeytinyağlarının satışının yasaklanması konusundaki kararın 13 Aralık 1886 tarihi itibariyle kendilerine ulaştığını, ancak bu kararın uygulamasının Fransız ticaretini olumsuz etkileyeceğini ifade ederek, Osmanlı Devleti'ni aldığı kararı değiştirmesi için baskı altına almaya çalışmıştır. ${ }^{30}$ Sefaret, zeytinyağlarının sınırlı ölçüde mahlût olması durumunda bunu tespit edebilecek bir yöntemin henüz Fransa'da bile olmadığını öne sürmüş; Osmanlı hükümetinin kendi yaptırdığı tahlillere dayanarak birtakım tedbirler alması durumunda ise bunları uygulamakta müşkülata düşeceğini belirtmiştir. Fransız Sefareti, ayrıca, bu kanunun uygulanmasının yalnızca Fransa ticaretine değil, Osmanlı'nın zeytinyağı ihracatına da sekte vuracağını ileri sürerek alınması öngörülen tedbirlere itiraz etmiştir. Dahası, pamukyağının, zeytinyağına karıştırılıp tüketilmesinin sağlığa zarar vermeyeceğini belirten sefaret, Osmanlı hükümetinin pamukyağı konusundaki engellemelerini de bu sebeple gereksiz bulmuştur. ${ }^{31} \mathrm{Bu}$ itirazlar karşısında, Bab-1 Ali'nin alınan tedbirlere temel olarak kullanabileceği bilimsel bir dayanağa ihtiyaç duyduğu anlaşılmaktadır. Bu nedenle de konu, görüş bildirmesi için Meclis-i Tıbbiye-i Mülkiye ve Sıhhiye-i Umumiye'ye yönlendirilmiştir.

Meclis-i Tibbiye-i Mülkiye ve Sihhiye-i Umumiye, 25 Temmuz 1887 tarihli tafsilatlı bir rapor hazırlayarak konuya açıklık getirmeye çalışmıştır. Fransız Sefareti'nin itirazlarını haklı bulmadığını belirterek raporuna başlayan Meclis-i

29 BOA, DH.MKT, 1383/72 (9 Aralık 1886)

30 BOA, HR.TH, 74/10

31 BOA, HR.TH, 74/10 
Sıhhiye-i Umumiye, sefaretin ileri sürdüğ̈̈, hâlihazırda bitkisel yağların sınırlı ölçüde mahlût olması durumunda bunu anlamak için bir yöntem bulunmadığı yönündeki iddiasını kabul etmez. Rapor, zeytinyağı içinde yabancı yağların -özellikle de alınan tedbirlerin esas hedefi olan pamukyağının- mevcut olup olmadığının rahatlıkla anlaşılabileceğini belirtir. ${ }^{32}$ İkinci olarak, bu yağların sindirim veya sıhhat üzerindeki etkileri gibi mevzulara girmenin asıl sadedi terk etmek anlamına geleceği ifade edilerek, raporda bu konu tartışma dışı bırakılmıştır. Zeytinyağı ya da herhangi bir gıda maddesinin içine yabancı bir madde katılmasının daima hilekârlık ve sahtekârlık olarak değerlendirilmesi gerektiğini savunan Meclis, karıştırılan madde sağlıklı bir madde olmadığından bu işleme hiçbir şekilde izin verilemeyeceğini vurgulamıştır. Ayrıca, Osmanlı hükümetinin kanun ve nizamat ile bazı gıdalara yabancı maddelerin karıştırılmasını yasakladığına da dikkat çekilmiştir. Zeytinyağı yalnızca Osmanlı’nın en önemli mahsulâtı arasında yer almamakta, aynı zamanda ahali tarafından gıda maddesi olarak da tüketilmekteydi. Bundan dolayı Meclis-i Sıhhiye-i Umumiye, devletin halkın tükettiği bu gıda maddesinin saflığını korumakla yükümlü olduğu kanaatindeydi. Söz konusu raporda, Fransa’da da halk sağlığını korumak için benzeri önlemler alındığının altı çizilerek, özellikle Paris Belediye Laboratuvarı'nın uygulamalarına ve oralarda yapılan tahliller sonucunda hükümete aldırılan tedbirlere dikkat çekilmiştir. Buradan hareketle Meclis-i Sıhhiye-i Umumiye, Osmanlı Devleti'nin de sıhhat-1 umumiyeyi koruyan önlemleri almaya hakkı olduğunu göstermeye çalışmıstır. ${ }^{33}$

Meclis-i Sıhhiye-i Umumiye, son olarak, Osmanlı Devleti'nin aldığı önlemlerle serbest ticareti engellediği iddialarına da cevap vermek ihtiyacını hissetmiştir;

32 Gerçekten de bu dönemde gıda analizleri için çeşitli analiz yöntemleri gelişmişti. Zeytinyağı içinde pamukyağı olup olmadığını tespit etmek için de Hübl, Halphen, Bechi, Maumené number, Milliau, Tortelli and Ruggeri, Muter ve Brulle gibi birden fazla analiz yöntemi bulunmaktaydı. Ayrıntılı bilgi için bkz.: O. Bach, "The Testing of Olive Oil,” The American Journal of Pharmacy, 55 (Temmuz 1883), s. 354-357; Ch. Marie, "The Adulteration of Olive Oil," The American Journal of Pharmacy, 55 (Temmuz 1883), s. 25-27; Samuel P. Sadtler, A Handbook of Industrial Organic Chemistry (Philadelphia: J.B. Lippincott Company, 1892), s. 72-77; "An Easy Test for Olive Oil," Scientific American, 44/8 (19 Şubat 1881), s. 120; Oscar C. S. Carter, "On the Detection of Adulterations in Oils," Proceedings of the American Philosophical Society, 22/120, Part IV (Ekim 1885), s. 296-299; Azor Thurston, Pharmaceutical and Food Analysis (New York: D. Van Nostrand Company, 1922), s. 90-110; Tolman ve Munson, Olive Oil and Its Substitutes, s. 13-34.

33 BOA, HR.TH, 74/10. Paris Belediye Laboratuvarı hakkında ayrıntılı bilgi için bkz.: Atkins, Stanziani, "From Laboratory Expertise to Litigation,” s. 317-339; Stanziani, "Municipal Laboratories and the Analysis of Foodstuffs," s. 105-115. 
çünkü Fransız Elçiliği itirazında Osmanlı hükümetinin mahlût yağlar konusundaki uygulamasının 1861 Ticaret Anlaşması' na ${ }^{34}$ uygun olmaması nedeniyle yürürlükten kaldırılmasını talep etmekteydi. Bu itirazlar karşısında, ticaretin her şeyden önce saf-halis maddelerin mübadelesinden ibaret olduğunun altını çizen Meclis, mahlût ve hileli ürünlerin mübadelesinin hiçbir yerde meşru ticaret kapsamında değerlendirilemeyeceğini vurgulamak suretiyle, tağşişi yasaklayan tedbirlerle meşru ticaretin ihlal edilmeyeceğini bilakis korunacağını savunmuştur. Meclis-i Sıhhiye-i Umumiye, Fransız Sefareti'nin hilekâr tüccarı himaye etmek istemeyeceğine emin olduğunu da imalı bir biçimde belirtir. Oluşturduğu bu rapor ile hükümetin aldığı tedbirlerin arkasında duran Meclis-i Sıhhiye-i Umumiye, mahlût yağlarla ilgili uygulamanın değiştirilmemesini isterken, ahalinin gıda tağşişine karşı korunması gerektiği sözleriyle raporunu sonlandırmıştır. ${ }^{35}$ Anlaşıldığı üzere, hem Cemiyet-i Tıbbiye-i Mülkiye hem de Meclis-i Tibbiye-i Mülkiye ve Sıhhiye-i Umumiye gibi kurumlar, kamu sağlığının korunması noktasında tereddütsüz bir pozisyon almış ve hükümeti de bu konuda tarafgir olmaya zorlamıştır. Gıda güvenliğini halk sağlığının temel direklerinden biri olarak sayan bu anlayış sayesinde, Osmanlı hükümeti de tağşiş işlemi karşısında aldığı önlemleri uluslararası alanda savunabilir hale gelmiştir.

Mahlût zeytinyağlarının "zabt ve müsaderesi” ile tağşiş işine karışanlar hakkında gerekli cezaların icrası hakkında karar alınmış olmakla birlikte, arşiv belgelerinden anlıyoruz ki pamukyağının gümrüklerden geçişinde herhangi bir engel olmadığı

34 Bilindiği üzere Osmanlı Devleti 1838 yılında İngiltere ile Serbest Ticaret Anlaşması imzalamış ve bu anlaşmanın ardından diğer Avrupa devletleriyle de benzer şartlar içeren başka anlaşmalar imzalanmıştır. Osmanlı Devleti, söz konusu anlaşmalarla dış ticarette egemen bir devletin sahip olması gereken belirleyiciliği büyük ölçüde kaybetmiş, bu tarihten itibaren bağımsız bir dış ticaret politikası izleyememiştir. Ayrıntılı bilgi için bkz.: Şevket Pamuk, Osmanlı Ekonomisinde Bağımlılık ve Büyüme 1820-1913 (İstanbul: Tarih Vakfı Yurt Yayınları, 2005), s. 17-19. 1861 ve 1862 yıllarında ise Osmanlı Devleti ile Avrupa Devletleri arasında yeni ticaret anlaşmaları imzalanmıştır. Yukarıda bahsi geçen anlaşma, bu kapsamda 29 Nisan 1861 tarihinde Fransa'yla imzalanan ve gerek iç gerekse dış ticarette Fransa’ya tam serbestlik sağlayan ticaret anlaşması olmalıdır. Ayrıntılı bilgi için bkz.: Enver Ziya Karal, Osmanlı Taribi VII. Cilt, Islahat Fermanı Devri (1861-1876) (Ankara: TTK Basımevi, 2003), s. $260-261$.

35 BOA, HR.TH, 74/10. Fransız Sefareti ve Osmanlı kurumları arasında tağşiş konusunda ortaya konan argümanların pek çoğu, 19. yüzyıl ortalarında Avrupa kamuoyunda da tartışma konusu olmuştur. Gıda güvenliğine bir halk sağlığı meselesi olarak mı, yoksa adil ticareti ihlal eden bir sahtekârlık olarak mı yaklaşılacağı; tağşiş için gıdanın içine konan maddenin sağlığa zararı olmaması durumunda mahlût ürünlerin ne şekilde değerlendirileceği gibi mevzularda farklı görüşler Avrupa ülkelerinin gündemini işgal etmiştir. Peter Scholliers, "Food Fraud and the Big City: Brussels," s. 80. 
için yağların tahlit edilmesinin önü alınamamıştır. Bu noktada Osmanlı Devleti, zeytinyağı tağşişine karşı kesin bir çözüm bulabilmek amacıyla bir adım daha ileriye gitmiş ve pamukyağları için men-i ithal kararı almıştır. ${ }^{36}$ Pamukyağı sahiplerinin ilgili yasaklama kararından zamanında haberleri olmadıkları iddiasıyla zarara uğradıkları yolunda ileride gerçekleşebilecek şikâyetlerini henüz gerçekleşmeden engellemek ve kamuoyunu bilgilendirmek için de gazetelerle ilan yoluna başvurulmuştur. Osmanlı Devleti, aldığı men-i ithal kararının yürürlüğe girmesi için yasağın gazetelerde ilan edilmesinden itibaren altmış bir günlük bir süre öngörmüştür. ${ }^{37}$

Gazetelerde men-i ithal kararının yayınlanmasının ardından başta Fransa olmak üzere yabancı ülke temsilciliklerinin tekrar harekete geçtiği görülmektedir. Fransız Sefareti 26 Aralık 1887 tarihli takririyle, pamukyağı ve bu yağ ile imal olunan sabunların Osmanlı ülkesine girişini yasaklayan karardan gazetelerde yayımlanması suretiyle haberdar olduklarını, ancak Meclis-i Mahsus-u Vükela tarafından alınan bu kararın 1861 tarihli ticaret anlaşması ile temin olunan Fransız serbest ticaretine sekte vuracağını ifade etmiştir. Ayrıca bu kararın uygulanması nedeniyle Fransa'nın uğrayacağı zarar ve ziyandan Bab-1 Ali'yi mesul tutacağının altını çizmiştir. ${ }^{38}$ Yine İngiliz Sefareti de İngiliz ticari menfaatlerine zarar verecek söz konusu karar karşısında Fransız Sefareti'nden verilen 26 Aralık 1887 tarihli takrire iştirak ettiğini belirtmiş ve mevcut ticari anlaşmalara aykırı olan men-i ithal uygulaması nedeniyle İngiliz ticaretinin uğrayacağı zarar ve ziyan için Osmanlı hükümetini mesul tutmaya mecbur olduğunu bildirmiştir. ${ }^{39}$

Dünyanın en önemli sabun üreticilerinden olan, özellikle de Marsilya sabunları tüm dünyada tanınan Fransa’nın konuyla ilgili itirazlarının ilerleyen süreçte de devam ettiği görülmektedir. Fransız Sefareti, Şubat 1888 tarihli notasıyla pamukyağının sağlığa zararlı olduğu iddialarına yine karşı çıkmıştır. Sefaret, pamukyağının içinde gerçekten zararlı kimi unsurlar bulunmuş olsaydı, bu durumun alanında

36 Aslında men-i ithal kararından önce, ithal edilecek pamukyağlarının, makinelerde kullanımına engel olmayacak ancak gıda olarak tüketilmelerinin önüne geçecek şekilde, içine havaciva boyası katılarak renklerinin değiştirilmesi ve bu yolla ithallerine izin verilmesi düşünülmüştür. Ancak Meclis-i Vükela müzakerelerinde pamuk yağının makinelerde kullanımının pek de lüzumlu olmadığı Bahriye Nezareti’nden ifade edilince, pamukyağının Memalik-i Şahane'ye külliyen men-i ithali kararı alınmıştır. BOA, DH.MKT, 1432/24 (14 Temmuz 1887); BOA, MV, 22/1 (18 Temmuz 1887); BOA, A.MKT.MHM, 494/23 (18 Temmuz 1887).

37 BOA, DH.MKT 1460/55 (3 Kasım 1887); BOA, DH.MKT, 1462/26 (10 Kasım 1887)

38 BOA, HR.TO, 207/74 (26 Aralık 1887)

39 BOA, HR.TO, 263/44 (29 Aralık 1887) 
yetkin kimyagerler olan Paris Belediyesi Kimyagerleri tarafindan daha önce tespit edileceğini, dolayısıyla da pamukyağı kullanımının çoktan yasaklanmış olacağını ileri sürmüştür. Pamukyağı kullanımının tehlikeli olmadığını ve böyle bir yasaklamaya da gerek olmadığını yazan sefaret, gazetelerde ilan edilen tedbirin Fransız tebaasına uygulanmasına karşı çıkmıştır. Bu durum nedeniyle Fransa ticaretinin uğrayacağı zarardan Bab-1 Ali'nin mesul tutulacağı konusundaki uyarı da yinelenmiştir. ${ }^{40}$ Mayıs 1888 'de Fransa'nın bir kez daha men-i ithal kararının dayanaklarını sorguladığını ilgili arşiv belgelerinden takip edebilmekteyiz. Sefaret, Osmanlı Hükümeti'nin 1886 yılında mahlût yağlar karşısında birtakım önlemler aldığını, fakat önlemlerin kapsamının genişletilerek saf pamukyağlarının yasaklanması için bir neden olmadığını iddia etmiştir. 1861 anlaşmasına atıfla serbest ticaretin ihlal edildiği argümanı da tekrar kullanılır. ${ }^{41}$

Büyük devlet elçiliklerinden özellikle de Fransa'dan gelen itirazlar sonucunda Osmanlı Hükümeti, saf pamukyağlarının ithalinin yasaklanmasının serbest ticareti ihlal edeceği argümanını kabul etmiş ve 1888 yılının Temmuz ayında pamukyağı ithalini külliyen yasaklayan kararını değiştirmiştir. Hükümete göre, asıl maksat pamukyağının zeytinyağına karıştırılmasını engellemek olduğundan, yağın renginin değiştirilerek (telvin edilerek) gıda olarak tüketiminin önüne geçilmesi şartıyla, ithalinde bir sakınca olmayacaktı. Bu çerçevede ithalattaki yasaklamadan vazgeçilmiş ve pamukyağlarının renginin değiştirilerek ithaline izin verilmiştir. ${ }^{42}$ Gümrüklere gelen mahlût yağların ve pamukyağının yiyecek olarak tüketilmelerini önlemek için içlerine gaz yağı katılarak renginin değiştirilmesi uygulaması da bu süreçte başlamıştır. Yağlara ilave olunacak maddelerin masrafı yağ sahibi tarafından ödenmek durumunda olduğundan, bu durumun sefaretlere tebliğ edilmesi gerektiği de Rüsumat Emaneti'nce ifade edilmiştir. Ancak alınan bu kararın uygulanmasında birtakım sorunlar çıktığını yine ilgili arşiv belgesinden anlayabilmekteyiz. Belgede mahlût yağlar ve pamukyağı içine yüzde kaç oranında gaz yağı döküleceği konusunda bir netlik olmadığı vurgulanmış ve gaz yağının pamukyağına karıştırıldıktan

40 BOA, HR.TO, 207/78 (Şubat 1888)

41 BOA, HR.TO, 207/87 (16 Mayıs 1888). Söz konusu tedbirler açıktır ki en çok Fransız Elçiliği'ni rahatsız etmiş, meseleye dair itiraz kaydı koyduğunu defalarca Osmanlı Hariciye Nezareti'ne bildirmiştir. İlaveten, pamuk yağlarının sıhhat-1 umumiyeye zarar verdiğine dair Mekteb-i Tıbbiye-i Şahane tarafından hazırlanan ve Osmanlı Devleti'nin men-i ithal kararına dayanak sağlayan fenni raporların birer suretini de talep etmiştir. BOA, HR.HMŞ. İŞO, $173 / 6$.

42 BOA, DH.MKT, 1525/15 (25 Temmuz 1888) 
sonra tasfiye edilebileceğinin altı çizilmiştir. ${ }^{43} \mathrm{Bu}$ noktada doğru yöntemi tespit edebilmek için Tıbbiye Nezareti'ne danışıldığı görülmektedir. Tıbbiye, söz konusu yağların gaz ve neft gibi kokulu maddeler yerine "orkanet", yani havaciva, katılarak telvin edilmesini önermiştir. ${ }^{44}$

Şunu da belirtmek gerekir ki, mahlût yağlardan duyulan rahatsızlık sadece kamu otoritelerinden kaynaklanmıyor; zeytinyağ 1 üreticileri de dönem dönem hükümet idarelerine ve rüsumat emanetine başvurarak pamukyağına ve mahlût yağlara karşı önlemler alınmasını istiyordu. Üreticiler, mahlût yağların, saf zeytinyağlarına göre daha ucuz olmakla birlikte halk sağlığını bozucu ve yerel zeytinyağlarının yurt dışındaki itibarını düşürücü etkilerinden dem vuruyorlar ve bu doğrultuda pamuk yağının ülkeye girişinin ve karışık yağların satışının engellenmesini talep ediyorlardı. ${ }^{45}$ Osmanlı kamuoyunda tağşiş konusunda bir duyarlılık oluştuğunu gazetelere yansıyan reklamlardan ${ }^{46}$ ve çeşitli yayınlardan da anlayabilmekteyiz. ${ }^{47}$

43 BOA, HR.HMŞ.İŞO, 173/1 (23 Ağustos 1888)

44 BOA, HR.TH, 89/75 (6 Haziran 1889). Havaciva maddesi Alkanna tinctoria, alkanet ve orchanet olarak da adlandırılmaktadır.

45 Midilli üreticilerinin bu konudaki başvuruları konusunda bkz.: Ünver, "Midilli Adası,” s. 384. Gümrüklerde yalnızca pamukyağı değil başka pek çok yiyecek, içecek ve tıbbi maddenin analizi de yapılmaktaydı. Bu çerçevede ayçiçeği ve susam yağlarının zararlı maddeler olup olmadıkları ve ithallerine izin verilip verilmeyeceği de arşiv belgelerine konu olmuştur. Meclis-i Tıbbiye-i Mülkiye ve Sıhhiye-i Umumiye, bu yağların zararlı olmadığını, ancak sindirimi alışmaya bağlı olduğundan, alışmayan ve midesi zayıf kimselere dokunabileceğini belirtmiştir. İlgili ifade üzerine bu yağların ithaline müsaade edilmiştir. BOA, HR.HMŞ. İŞO, 190/49.

46 Gazete reklamlarında ürünlerin saflı̆̆ına ve zararlı maddeler içermediğine dair vurgular ile birlikte sahte ve hileli ürünlerden uzak durulması çağrıları ve ürünlerde kullanılan malzemelerin istenmesi durumunda tahlil ettirilebileceği gibi ifadeler, gıda sahtekârlı̆̆ına karşı kamuoyunda bir hassasiyet oluştuğunu göstermektedir. Ayrıntılı bilgi için bkz., Kemalettin Kuzucu, "Gazete Reklamlarına Göre Osmanlı'nın Son Asrında İstanbul'un Beslenme Hayatına Bakış," I. Türk Mutfak Kültürü Sempozyumu, 14-15 Ekim 2010-Bilecik (Bilecik: Bilecik Şeyh Edebali Üniversitesi Yayınları, 2012), s. 425-460.

47 Bu makalenin kapsamını aşmakla birlikte, gıda tağşişi konusunda Osmanlı kamuoyunda gerçekleşen tartışmalar, meselenin diğer bir yüzünü oluşturmaktadır. Bu çerçevede Maarif Dergisinnin 16 Kasım 1893 tarihli 121. sayısında Osmanlı kamuoyunu bilgilendiren bir makale yayınlandığını görmekteyiz. İlgili makalede zeytinyağının saf olup olmadığını tespit etmek için "Brulle" testinin kullanılabileceği ifade edilip, testin nasıl yapılacağı da açılanmıştır. "Saf Zeytinyağlarıyla Tabii ve Margarinli Tereyağları Nasıl Tanılır?," Maarif, 121 (4 Teşrin-i Sani 1309), s. 268. Osmanlı kamuoyunun gelişimi konusunda ayrıntılı bilgi için bkz., Murat Remzi Şiviloğlu, "The Emergence of Public Opinion in the Ottoman Empire (1826-1876)" (Yayımlanmamış Doktora Tezi), University of Cambridge, 2014. 


\section{İthalattaki Denetimlerin Kaldırılması}

Daha önce belirtildiği üzere, Osmanlı Devleti 19. yüzyılın son çeyreğinde gıda tağşsişine karşı bir politika benimsemiş, bu kapsamda üretici ve tüketicileri korumak için ülkeye pamukyağı girişini denetlemeye ve mahlût yağların satışını engellemeye çalışmıştır. 1905 tarihli Gümrüklerce İcra Edilecek Muayene-i Sıhhiye Nizamnamesi'nin 19. maddesi de bu kapsamda yapılmış bir düzenlemedir:

Madde 19-Gümrüklere vürud eden yağlardan bilmuayene muhill-i sıhhat mevadd-1 muzırrayı havi bulunmasından veya kokmuş ve bozulmuş olmasından naşi ekle gayr-i salih bulunanların ithaline müsaade olunmaz. Sanayide istimal olunmak üzere getirilecek pamuk yağları bittelvin ve kezalik sanayide istimal olunacak şuhum ve züyut-u nebatiye-i saire mahlût olmamak ve isimleri müsemmalarına mutabık olmak şartıyla bilâ telvin imrar ettirilip heyet-i haliyeleriyle imrarı caiz olmayan her türlü yağların sahibi tarafından arzu edildiği halde usul-ü fenniyesine tatbikan badettelvin imrarına müsaade olunur. ${ }^{48}$

İlgili madde uyarınca sanayide kullanılmak üzere getirilen pamukyağları telvin edildikten sonra ülkeye alınırken, gıda olarak getirilecek pamukyağlarının gümrüklerden girişine müsaade edilmeyecekti. Ancak 1906 yılının sonuna geldiğimizde Osmanlı hükümetinin yirmi yıldır uyguladığı bu yasak hususunda bir tavır değişikliği içine girdiği görülmektedir. 1 Aralık 1906 tarihli Şura-yı Devlet kararında, pamukyağı tüketimine alışkın olmayan kişilerin çok fazla pamukyağı tüketmesi durumunda birtakım mide rahatsızlıkları yaşayabilecekleri ve fakat iyi bir şekilde arıtılmış pamukyağlarının ara sıra tüketiminin kişilere zarar vermesinin pek de olası olmadığı vurgulanmıştır. Böylece, pamukyağlarının insan sağlığına zararlı olduğu iddiasından geri adım atan Şura-yı Devlet, buradan hareketle pamukyağlarının boyanarak ülkeye alınması yönündeki nizamname maddesinin değişmesi gerektiğini ifade etmiştir. Fakat ilgili kararda şu noktaya da dikkat çekilmiştir: Pamukyağları zeytinyağına nispetle daha düşük fiyatlı olduğundan, ithal edildikten sonra erbab-1 ihtikâr tarafından zeytinyağı namıyla ya da zeytinyağına karıştırılarak satılabilirdi. Pamukyağlarının zeytinyağı tağşişinde kullanımını engellemek için, bu gibi yağları satan dükkân ve mağazaların belediyelerce sürekli teftiş edilmesi ve tağşiş işine girişenler hakkında cezai işlemlerin uygulanması gerektiği de bahsi geçen kararda belirtilmekteydi. ${ }^{49}$

48 "Gümrüklerce İcra Edilecek Muayene-i Sıhhiye Nizamnamesi (29 Rebiyülevvel 1323 ve 20

Mayıs 1321-2 Haziran 1905),” Düstur, 1. Tertip, 8. Cilt (Ankara: Başvekalet Devlet Matbaası, 1943), s. 249.

49 BOA, ŞD, 600/73 (1 Aralık 1906) 
22 Mayıs 1907 tarihinden itibaren de Osmanlı Devleti, pamukyağının ülkeye girişindeki denetimleri kaldırmıştır. Bu politika değişikliğinde Amerika Birleşik Devletleri'nin İstanbul büyükelçisi Edward H. Ozmun'un girişimlerinin etkili olduğu anlaşılmaktadır. ${ }^{50}$ Dünyanın en önemli pamuk üreticilerinden ve pamukyağı ihracatçılarından olan Amerikảnın ticaretini sınırlayacak her türlü engelden kurtulmak istemesi ve bu konuda diplomatik girişimlerde bulunması doğaldır ve anlaşılmaktadır ki Osmanlı Devleti Amerikan taleplerini kabul ederek kendi gıda politikasını değiştirmek durumunda kalmıştır. Osmanlı Devleti'nin bu Amerikan talebini kabul etmesinin ardında yatan neden ise, gümrük resminin arttırılması için Amerika ile yürüttüğü müzakerelerdir. Osmanlı Devleti 1861 ticaret anlaşmaları ile $\% 8$ olarak belirlenmiş olan gümrük resmini \%11'e çıkarmak istemekteydi. Bu \%3'lük artışı Amerika'ya kabul ettirebilmek için Osmanlı Devleti, telvin muamelesinin sadece saf olmayan-mağşuş pamukyağlarına uygulanmasını, buna karşın saf pamukyağlarının serbestçe ülkeye girişini kabul etmiştir. ${ }^{51}$ Osmanlı'nın pamukyağı ithalinde kontrolleri kaldırdığı bu süreçte, diğer pek çok Avrupa ülkesinin bu alanda korumacı politikaları uygulamaya devam ettiğini de belirtmek gerekir. Örneğin İspanya, kendi zeytin üreticilerini korumak adına pamukyağı ithalini tamamen engellemekte; Avusturya da benzeri bir gümrük yasağı uygulamaktaydı. Almanya, Fransa ve İtalya ise pamukyağının ülkeye girişini tamamen yasaklamasalar da bu yağları ağır bir şekilde vergilendirmekteydiler. Ancak alınan tüm tedbirlere karşın, pamukyağı kullanımında neredeyse tüm dünyada bir artış trendi olduğu da gözden kaçmıyordu. $^{52}$

Amerikan Ticaret Odasinnn (American Chamber of Commerce for the Levant) Doğu Akdeniz üzerine hazırladığı yayınlarda da, 1907 yılına kadar Osmanlı Devleti’nin gümrüklerde aldığı önlemler dolayısıyla Osmanlı’ya yemeklik

50 BOA, ŞD, 604/1 (6 Şubat 1910); BOA, HR.HMŞ.İ̧̧O, 199/74; Luther A. Ransom, The Great Cottonseed Industry of the South (New York: Oil, Paint and Drug Reporter, 1911), s. 98.

51 BOA, ŞD, 604/1 (6 Şubat 1910). 1838 Ticaret Anlaşması'na göre Osmanlı Devleti ithalat$\tan \% 5$, ihracattan ise $\% 12$ gümrük resmi alacaktı. 1861 yılında yapılan ticaret anlaşmaları ile ithalattan alınan vergiler \%8'e çıkarılırken, ihracattan alınan vergiler ilk yıl \%8 olarak belirlenmiş, fakat sonraki her y1 \%1 indirilerek nihayetinde \%1 düzeyine gelmiştir. 1905 yılına gelindiğinde dönemin büyük devletleriyle yapılan müzakereler sonucu ithalat resmi \%11'e yükseltilmiştir. Mübahat S. Kütükoğlu, Balta Limanina Giden Yol Osmanlı-İngiliz İktisadi Münasebetleri (1580-1850) (Ankara: Türk Tarih Kurumu, 2013), s. 277; Stanford J. Shaw, "The Nineteenth-Century Ottoman Tax Reforms and Revenue System," International Journal of Middle East Studies, 6/4 (1975), s. 444-446.

52 Ransom, Cottonseed Industry of the South, s. 24. 
pamukyağı ihracatına ciddi sekte vurulduğu; ancak yerel zeytinyağı üreticilerini korumak için konan yasağın 1907 yılında kaldırılmasıyla birlikte, pamukyağına olan talebin hızla arttığı ifade edilmektedir. ${ }^{53}$ İlgili yayında, Amerika Birleşik Devletleri'nin Osmanlı Devleti'ne pamukyağı ihracatının yıllara göre artış seyri de verilmektedir:

Tablo 1: Amerika'dan Osmanlı’ya pamukyağı ihracatı

\begin{tabular}{|c|c|}
\hline Yillar & Dolar Bazında İhracat Değeri \\
\hline 1907 & $6,860 \$$ \\
\hline 1908 & $208,000 \$$ \\
\hline 1909 & $943,000 \$$ \\
\hline 1910 & $470,000 \$$ \\
\hline 1911 & $957,000 \$$ \\
\hline 1912 & $803,000 \$$ \\
\hline 1913 & $888,000 \$$ \\
\hline 1914 & $352,000 \$$ \\
\hline
\end{tabular}

Kaynak: Norton, "Cotton Oil in Turkey”, s. 331.

Amerikan Ticaret Odası verilerinde de görüldügü üzere, pamukyăg ithalindeki denetimlerin kaldırılmasıyla birlikte, Osmanlı Devleti'ne yapılan ihracatta bir patlama yaşanmıştır. Bu muazzam artış trendi dolayısıyla Amerikan Ticaret Odası, Osmanlı'yı Amerikan pamukyağı üreticileri için iyi bir pazar olarak değerlendirmektedir. Bahsi geçen yayında tüketilen pamukyağının büyük kısmının zeytinyağını tağşiş etmek için kullanıldığı da açıkça belirtilmektedir. Tam da bu nedenle, zeytin hasadı iyi olduğunda pamukyağına olan talep azalırken, hasat kötü olduğunda zeytinyağını tağşiş etmek amacıyla pamukyağı kullanımı artmaktayd..$^{54}$

53 Thomas H. Norton, "Cotton Oil in Turkey," Levant Trade Review, 5/4 (March Quarter 1916), s. 330-331. Norton'un makalesinde aslında "Osmanlı Devleti” yerine "Türkiye” ifadesi kullanılmaktadır. Ancak yukarıda Norton’dan yapılan aktarımlarda, 1923 öncesi dönem ele alındığı için Türkiye yerine Osmanlı Devleti ifadesi kullanılmıştır.

54 Norton, “Cotton Oil in Turkey,” s. 330. “İzmir'de zeytin hasadı iyi olduğunda yıllık pamukyağı tüketimi 5,000 varil ortalamasında iken, hasat kötü olduğunda tüketim 8,000 varile çıkmaktadır" sözleri durumu özetlemektedir. 
Pamukyağının ülkeye girişine Osmanlı Hükümeti tarafından izin verilmesinin ardından ithalattaki yüksek artış, özellikle Midilli ${ }^{55}$ zeytinyağı üreticileri ve tüccarlarında ciddi bir rahatsızlık yaratmışıır. Pamukyağının temel kullanım alanının zeytinyağı tağşsisi olduğunun farkında olan yerel yönetimler de bölgelerindeki zeytinyağı üreticilerini korumak adına birtakım adımlar atmak durumunda kalmışlardır. Midilli'de yerel idari birimlere baskı yapan üreticiler, her ne kadar ithalat serbestîsi getirilmiş olsa da 1909 yılı Temmuz ayında pamukyağlarının gümrükten geçişine engel olmaya çalışmışlardır. Ancak Amerikan Elçiliği söz konusu engelleme karşısında Osmanlı Hükümeti'ne başvurmuş ve Dâhiliye Nezareti'nin müdahalesiyle gümrükte bekletilen yağların girişine izin verilmiştir. ${ }^{56}$

Geçimlerini zeytinyağı üretimi ve ticaretinden sağlayan Midilli ahalisinin pamukyağına karşı önlem alınması için yaptığı başvurulardan biri de tüccar Hasan Basri ve rüfekası imzalıdır. Yurtdışından külliyetle ithal edilmekte olan pamukyağlarının zeytinyağı tağşişinde kullanılması dolayısıyla yerli zeytinyağlarının kıymetinin ve bu yağlara olan rağbetin azaldığını belirten başvuru sahipleri, bu durum nedeniyle hem memleket ekonomisinin zarar gördüğünü hem de halkın geçim vasıtasından mahrum kaldığını ifade etmişlerdir. Gerek zeytinyağlarında gerek sabunlarda tağşişe engel olacak ciddi tedbirler alınmasını talep eden söz konusu başvurư ${ }^{57}$ üzerine devlet kurumları arasında kapsamlı yazışmalar yapılmıştır.

Konu hakkında görüş bildirmesi için öncelikle Tibbiye Nezareti ve Kimyahane’ya danışılmıştır. ${ }^{58}$ Kimyahane hazırladığı raporda, 22 Mayıs 1907'den önce zeytinyağı ticaretini muhafaza etmek ve yağların tağşişine engel olmak için Dersaadet, Galata ve diğer önemli limanların Rüsumat idarelerinde yağların muayene edildiğini; bu yağlardan pamukyağı olduğu anlaşılanların ise Gümrük Nizamnamesi’nin 19. maddesine uygun olarak telvin edildikten sonra ülkeye girişine izin verildiğine dikkat çekmiştir. Bu dönemde memlekete pek cüzi miktarda ve yaftalı şişeler içinde pamukyağları gelmekte iken, yabancı hükümetlerin nüfuzu sonucu 22 Mayıs 1907 'den beri nizamnamenin ilgili maddesi değiştirilmiş ve böylece saf pamuk

55 Midilli'de zeytinyağı ticaretinin tarihsel gelişimi konusunda ayrıntılı bilgi için bkz.: Zeki

Arıkan, "Midilli-İstanbul Arasında Zeytinyağı Ticareti," Ankara Üniversitesi Dil ve TarihCoğrafya Fakültesi Tarih Bölümü Tarih Araștırmaları Dergisi, 25/40 (2006), s. 1-28; Evridiki

Sifneos, "On Entrepreneurs and Entrepreneurship of the Olive-Oil Economy in the Aegean:

The Case of Lesvos Island," The Historical Review, I (2004), s. 245-273.

56 Ünver, "Midilli Adası," s. 384-385.

57 BOA, BEO, 3504/262742 (3 Mart 1909)

58 BOA, ŞD 604/1 
yağları telvin edilmeden ithal edilmeye başlanmıştır. Kimyahane, bu tarihten itibaren ülkeye giren pamukyağı miktarının çok fazla arttığını ve bu durumun hem Osmanlı ticaretine hem de Osmanlı tebaasına zarar verdiğini ifade etmiştir. Durum öyle bir hal almıştır ki Tıbbiye Nezareti Kimyahanesi, çeşitli nezaretlerden ve hususi olarak da Evkaf Nezareti tarafından kendisine zeytinyağı diye gönderilen numunelerin tahlillerinde bunların pamukyağı olduğunu tespit etmiştir. Yine Belediye Hıfzıssıhha Müfettişleri tarafından zeytinyağı diye gönderilen yağların da pamukyağı olduğu yapılan tahliller sonucu anlaşılmıştır. İstanbul'da dükkân, mağaza ve bakkallardaki zeytinyağlarının da ya mahlût yahut da pamukyağı olduğu açığa çıkmıştır. Bu şartlar altında, Kimyahane, memleketimizde ecnebi ülkelerden gelen pamukyağlarının milli yağımız olan zeytinyağının yerine geçtiği ve bir an önce önlem alınmazsa ülkemizde artık zeytinyağı ticareti yerine pamukyağı ticaretinin hakim olacağı tespitinde bulunur. İlgili raporda, ahalinin üç-dört kuruşluk pamukyağını zeytinyağı alıyorum zannıla on iki kuruşa aldığı, dolayısıyla yalnızca zeytinyağı ticaretiyle uğraşan Osmanlı tebaasının değil, zeytinyağı tüketmeye alışmış tüketicinin de bu durumdan zarar gördüğü vurgulanırken, bu işten kazançlı çıkanın ise pamukyağı üretenler ve satanlar olduğu belirtilir. Kimyahane bahsi geçen raporunda pamukyağlarının sıhhate olan zararından ziyade, "zeytinyağı ticaretini muhafaza ve zeytinyağı ile geçinen ahalimizi himayeye" önem verdiğinin alıını çizer. Buradan hareketle de tağşiş sorununa çözüm olarak, saf pamukyağlarının ancak birer kiloluk şişeler içinde ve yaftalı olarak ithal edilmesini; fiçılarla getirilecek yağlara ise eskisi gibi Gümrük Nizamnamesi'nin 19. maddesi gereğince muamele edilmesini, yani ithal edilen yağlar pamukyağı çıkarsa ancak telvinden sonra ülkeye girişine izin verilmesini, önermiştir. ${ }^{59}$ Umur-1 Tibbiye-i Mülkiye Kimyagerleri, telvin edilmiş pamukyağlarının sanayide kullanımında mahzur olduğu iddiasını da değerlendirmiş ve şu tespitlerde bulunmuştur: Esasen telvin usulü sabun imalatı gibi faaliyetlere dikkate değer bir etkide bulunmamakta, fakat pamukyağlarının

59 BOA, ŞD, 2786/4 (39. Belge ve 35. Belge). Dersaadet Hıfzıssıhha-i Umumiye Müfettişlerinden Nuri Bey de, Osmanlı fabrikalarında kullanılmak üzere ithal edilmekte olan yüz binlerce kıyye pamukyağıyla mevcut fabrikaları kıyasladığında, söz konusu yağların sanayide kullanılmaktan ziyade zeytinyağlarını tahlit için kullanıldığını ve ahaliyi pamukyağı yemekten kurtarmak için gümrükte telvin edildikten sonra ülkeye girişine izin verilmesi gerektiğini vurgulayan bir takrir vermiştir. Umur-1 Tıbbiye-i Mülkiye Kimyagerleri, bu takrire dair mütalaalarında yabancı memleketlerden gelen ürünlerin sıhhi muayenelerini yapan Dersaadet ve taşra gümrüklerindeki yirmi beş kimyahanede pamukyağlarının tekrar Gümrük Nizamnamesi'nin 19. maddesine göre boyanmaları durumunda, mağşuş ve mahlût yağlardan kaynaklı zararların önünün alınabileceğini teyit etmiştir. BOA, ŞD, 2786/4 (31. Belge). 
zeytinyağı tağşişinde kullanılmasına veya zeytinyağı diye satılmasına engel teşkil etmektedir. Kimyagerlere göre, telvin işlemine karşı çıkılmasının esas nedeni de zaten bu durumdur. ${ }^{60}$

Şehremaneti de mahlût yağlar konusunda alınan zıt kararlardan yakınmaktaydı. Belediye, tağşişle mücadele ekseninde mahlût yağları toplarken; bu yağların sahipleri, hükümetin aldığı farklı kararları dayanak göstererek mahkemelerde belediyeyi tazminata mahkûm ettirmişti. Bunun üzerine Şehremaneti, bu gibi durumların bir daha ortaya çıkmaması için hükümetin net bir karar alarak kendilerine bildirmesini istemiştir. Şehremaneti'nin dikkati çektiği bir diğer husus da, dâhilde üretilen yağların saflığını korumak ve revacını arttırmak için ülke içinde üretilmiş mahlût yağların yasaklanması konusundaki kararla alakalıdır. İlgili karar uyarınca dâhilde mahlût yağ imalatının yasaklanması, tespit edilen mahlût yağlara el konulması ve bu yağların sahiplerinin cezalandırılması gerekmekteydi; ancak yabancı memleketlerden "mevad-ı muzırradan arî namıla" külliyetli mahlût ve mağşuş yağlar ithal edildiği için, dâhildeki mahlût ve mağşuş yağlarla mücadele de mümkün olmuyordu. İstanbul'da türlü türlü mahlût yağ yapan dükkân ve fabrika sahiplerinin, yabancı ürünlerin önünü açan ancak dâhili ürünleri engelleyen muhtelif kararlar nedeniyle, bu işleri yabancı ülkeler tabiiyetindeki birtakım kişiler adına icra etmeye başladığı ve Belediye Daireleri ile Heyet-i Sıhhiye Müfettişliği'nin bunları engelleyemediği ilgili yazıda bildirilmekteydi. Ayrıca Şehremaneti’ne göre, yabancı ülkelerden gelen yağlara herhangi bir müdahalede bulunulmazken, dâhilde üretilenlerin yasaklanması adil ve eşitlikçi bir uygulama olmayacaktı. Böylesi bir uygulama yabancı menşeli ürünlerin itibarını arttıracak, dâhili üretime ise zarar verecekti. Bu durumu uygun bulmadığını belirten Şehremaneti, bu hususları düzenleyecek bir nizamnamenin hızlıca tanzim edilmesini ve hem ülke içinde üretilen hem de ithal edilen ürünler hakkındaki kararların aynı zamanda yürürlüğe girmesini istemiştir. ${ }^{61}$ Meclis-i Umur-1 Tibbiye-i Mülkiye ve Sıhhiye-i Umumiye de Kimyahane raporları ekseninde "telvin" in tağşsis karşısında hala uygulanabilecek en etkin yöntem olduğu fikrine iştirak etmiştir. Ancak eğer bu yapılamıyorsa her yağın kendi adı altında ülkeye girişi ve Şehremaneti'nce teftişat ve takibata tabi tutularak tağşişe cüret edenlerin cezalandırılması tavsiyelerinde bulunmuştur. ${ }^{62}$

Bütün bu yazışmalar sonucu hem ülke içinde üretilen hem de dışarıdan ithal edilen mahlût ve nebati yağlar hakkında iktisat ve hıfzıssıhha çerçevesinde hem

$60 \mathrm{BOA}$, ŞD, 2786/4 (32. Belge).

$61 \mathrm{BOA}$, ŞD, 2786/4 (37. Belge, 3. Belge ve 38. Belge).

62 BOA, ŞD, 2786/4 (30. Belge) 
memleket ihtiyaçlarına hem de devletin menfaatine uygun yeni bir nizamname layihası tanzim edilmesi kararı alınmıştır. Bu nizamname layihasını hazırlamak için de Hariciye Nezareti, Şehremaneti, Rüsumat Müdüriyet-i Umumiyesi, Heyet-i Sıhhiye ve Meclis-i Umur-1 Tibbiye-i Mülkiye ve Sıhhiye-i Umumiye ile Ticaret Odası memurlarından oluşan bir komisyon teşkil edilecekti. ${ }^{63}$

Yeni bir nizamname hazırlanması kararı alınmış olmakla birlikte, geçim vasıtalarını korumak isteyen zeytinyağı üreticileri ve tacirlerin şikâyetleri kesilmemiştir. Yağların gümrükten geçişine engel olamayan Midillili zeytinyağı üreticileri, bir başka çözüm düşünmüşler ve 1910 yılında Amerika'dan ithal edilen pamukyağı üzerine ağır bir tüketim vergisi konulmasını talep etmişlerdir. Söz konusu talep üzerine mevzu Şura-yı Devlet gündemine gelmiştir. Konuyu müzakere eden Şura-yı Devlet, öncelikle böyle ağır bir tüketim vergisi konması durumunda yabancı sefaretlerin, özellikle de Amerika'nın, buna itiraz edeceği; itirazlar gelmese bile böyle bir tüketim vergisinin sadece ülke içinde kullanılacak ürünlere uygulanabileceği, ihraç maddelerine uygulanmasının ise mümkün olmayacağı tespitinde bulunmuştur. Şura-yı Devlet kararında vurgulanan ikinci nokta, son birkaç seneden beri Osmanlıda zeytin fiyatlarının hayli yükselmiş olduğudur. Mahlût zeytinyağının fiyatı ise saf yağlara nispetle daha düşük olduğundan, bu yağların fukara ahalinin ihtiyacını karşıladığının alı çizilmiştir. Dolayısıyla pamukyağının ağır bir vergiye tabi tutulması halinde, bu durum fukara ahaliyi de etkileyecekti. Bahsedilen nedenlerden dolayı Şura-yı Devlet, ihracat için gümrüklerden geçecek olan zeytinyağlarının tetkik edilerek, bunların arasından karışık olanların "mahlût" yazılı bir mühürle mühürlenmesi gibi tedbirlerle yetinilmesi önerisinde bulunmuştur. ${ }^{64}$ Faruk Doğan’ın aktardığına göre Midilli halkının ülkeye pamukyağı ithalinin serbest bırakılmasından duyduğu rahatsızlık ileriki yıllarda azalmamış, aksine artmıştır. Bu rahatsızlık öyle bir noktaya gelmiştir ki 1913 yılında adaya pamukyağı ithal eden yerli bir tacir ve İtalyan tebaasından birine karşı sekiz-on bin kişilik nümayişler

63 BOA, ŞD 604/1; BOA, BEO, 3713/278459. Pamuk yağının telvin edilmeden ülkeye girişi yönünde karar alınmasına rağmen, yerelde pamukyağı girişini engellemeye yönelik girişimler olduğunu Temmuz 1909 tarihli başka bir Dâhiliye Nezareti belgesinde de görmekteyiz. Bahsi geçen belgede Karabiga'da pamukyağı girişine engel olunduğu ve yağların telvin edilmek istendiği ifade edilmiştir. Bu durum karşısında Dâhiliye Nezareti, mahlût yağların zararlı madde içermeyen ve yenebilir olanlarının sahiplerine iade edilmesi, ancak kapları üzerinde içeriğini gösteren bir yafta bulunmaması durumunda sattırılmaması gerektiğini bildirmiştir. Zararlı madde içeren ve sağlığa zararlı olabilecek yağların ise müsadere edilmesi gerekmekteydi. BOA, DH.MKT, 2885/28 (27 Temmuz 1909).

64 BOA, HR.HMŞ.İ̧SO, 199/74 (21 Şubat 1325-6 Mart 1910). 
bile düzenlenmiştir. Doğan, Edremit’teki Balya Maden Şirketi’ne karşı da benzeri bir tepkinin gündeme geldiğini ifade etmektedir. ${ }^{65} 1907$ 'de pamukyağ 1 ithalinin önünün açılmasının ardından Osmanlı zeytinyağı üretici ve tacirlerinin ciddi sorunlar yaşadığını irdelenen arşiv belgelerinden rahatlıkla izleyebilmekteyiz. Ancak Osmanlı Devleti'nin gümrük vergilerini yükseltme ihtiyacı, öyle gözükmektedir ki devletin iktisadi durumu açısından zeytinyağı tağşişinden çok daha yakıcı bir soruna işaret etmekteydi. Bu durum nedeniyle de devlet, yinelenen şikâyetlere rağmen önleyici tedbirler almak yoluna tekrar başvuramamıştır.

\section{Sonuç}

Özellikle 19. yüzyılın son çeyreğinden itibaren zeytinyağı gibi ürünlerin uluslararası ticarete daha çok konu olması, hem tağşiş için kullanılan kimi maddeleri hem de mahlût ürünleri piyasalarda daha kolay ulaşılabilir hale getirmiştir. Artan rekabet ortamında kapitalist piyasa koşullarına uygun bir şekilde ürünlerini daha ucuza piyasaya sürmek isteyen üreticilerin yahut tüccarların bir kısmı tağşiş yoluna başvururken, bu amaçla kullanılan kimi maddelerin insan sağlığına zarar vermesi, meseleye halk sağlığı boyutu da katmıştır. Yukarıda mahlût zeytinyağları meselesinde örneklendiği gibi, gıda maddelerinin tağşşşi özellikle uluslararası ticaretin yaygınlaştığı 1850 'lerden sonra Osmanlı Devleti için ciddi bir sorun haline gelmişti. Bu dönem aynı zamanda kamusal politikaların devletlerin gündemine girdiği ve Osmanlı hükümetinin de sıhhat-ı umumiye'nin korunması adına adımlar attığı sürece tekabül etmekteydi. Ancak Osmanlı Devleti’nin atacağı adımların bir sınırı vardı 1838 Balta Limanı Anlaşması ile başlayan ve imzalanan diğer ticaret anlaşmalarıyla perçinlenen süreçte, Osmanlı Devleti’nin bağımsız bir dış ticaret ve gümrük politikası izleme olanağı ortadan kalkmışı. Dolayısıyla Osmanlı Devleti, tağşiş karşısında bir adım atacağı zaman konunun uluslararası diplomatik ve ticari boyutunu da dikkate almak zorundaydı. İncelenen belgelerde de görüldüğü üzere, Osmanlı hükümeti bir taraftan tağşiş karşısında tedbirler almaya çalışırken, diğer taraftan uluslararası baskıları göğüslemeye çalışıyordu. Bu süreçte Osmanlı Devleti, önemli bir zeytinyağı ihracatçısı olan Fransa ile dünyanın en büyük pamukyağı ihracatçılarından olan Amerika Birleşik Devletleri sefaretlerinin talepleri, itirazları ve baskıları altında kendine bir hareket alanı yaratmaya çalışmıştır. Ancak bahsedilen hareket alanının sınırlı olduğunu ve Osmanlı Devleti'nin halk sağlığı, dış ticaretten gelir elde etme ve yerel üreticileri koruma gibi ikilemler içine düştüğünü de tespit

65 Doğan, "Osmanlı Devleti’nde Zeytinyağı," s. 139. 
etmek gerekir. Nihayetinde, gümrük vergisini $\% 8$ 'den \%11'e yükseltebilmek adına, zeytinyağları konusunda koruyucu politikalardan geri adım atılmış ve pamukyağının ülkeye girişinin yolu açılmıştır. Bu sürecin analizi, kamu sağlığı meselesinin sadece sağlık kriterleriyle belirlenmediğini, uluslararası siyaset ve ekonomi gibi etkenlerle de ilişkili olduğunu ortaya koymaktadır. Ancak şunu da ifade etmek gerekir, Osmanlı Hükümeti gıda güvenliğiyle ilgili kararlarını, pek çok dengeyi gözeterek, uluslararası baskılar, ticari beklentiler ve iktisadi zorunluluklar altında almış olsa da; Tıbbiye ve Kimyahane gibi kurumlar bu baskılardan azade, memleket ekonomisi ve menfaatini korumak adına daha idealist tavırlar sergilemişlerdir.

\begin{abstract}
Özロ 19. yüzyılın ortalarından itibaren kamusal sağlık uygulamaları hükümetlerin temel politika alanları içine girmiş, bu çerçevede halk sağlığını korumak adına çeşitli adımlar atılmıştır. Halk sağlı̆̆ının korunmasının bir ayağını halkın güvenilir gıda maddelerine ulaşması oluşturmaktadır. 19. yüzyılda ulaşım imkânlarının ve kapitalizmin gelişimi sonucu uluslararası düzeyde muazzam bir meta akışı doğmuş, gıda maddelerinde "tağşiş" -yani bir maddenin içine başka bir madde karıştırarak saflığını bozma- tüm dünyada önemli bir sorun olarak gündeme gelmiştir. Kapitalist dünya ekonomisine eklemlenen Osmanlı Devleti'nde de 1850'lerden itibaren gıda güvenliği çözüm bulunması gereken bir mesele haline dönüşmüş, devlet tağşiş karşısında birtakım tedbirler almak durumunda kalmıştır. Ancak alınan önlemler yine bu dönemde imzalanmış serbest ticaret anlaşmaları dolayısıyla uluslararası ticari ilişkileri olumsuz etkilemiş ve yabancı elçilikler konuya müdahil olmuştur. Bu çalışma gıda güvenliği meselesini mahlût (karışık) zeytinyağları üzerinden detaylandırarak incelemeye çalışacaktır.
\end{abstract}

Anahtar kelimeler: Halk Sağlığı, Gıda Güvenliğ̣i, Gıda Tağşişi, Zeytinyağı, Pamukyağı.

\title{
Bibliyografya
}

\section{Arşiv belgeleri}

Başbakanlık Osmanlı Arşivi (BOA), BOA, A.MKT.MHM, 494/23; BOA, BEO, 3504/262742; BOA, BEO, 3713/278459; BOA, DH.MKT 1460/55; BOA, DH.MKT, 1383/72; BOA, DH.MKT, 1432/24; BOA, DH.MKT, 1462/26; BOA, DH.MKT, 1525/15; BOA, DH.MKT, 2885/28; BOA, HR.HMŞ.IŞO, 173/1; BOA, HR.HMŞ. İŞO, 173/25; BOA, HR.HMŞ.İŞO, 173/6; BOA, HR.HMŞ.İŞO, 190/49; BOA, HR.HMŞ.İŞ, 199/74; BOA, HR.TH, 74/10; BOA, HR.TH, 89/75; BOA, HR.TO, 207/74; BOA, HR.TO, 207/78; BOA, HR.TO, 207/87; BOA, HR.TO, 263/44; BOA, MV, 22/1; BOA, ŞD, 2786/4; BOA, ŞD, 600/73; BOA, ŞD, 604/1. 


\section{Yayımlanmıs Eserler}

“An Easy Test for Olive Oil”, Scientific American, 44/8 (19 Şubat 1881), s. 120.

"Saf Zeytinyağlarıyla Tabii ve Margarinli Tereyağları Nasıl Tanılır?”, Maarif, 121 (4 Teşrin-i Sani 1309), s. 268.

Adulteration of Food, Drink and Drugs, London: 1855.

Aksakal, Layla J.: "The Sick Man and His Medicine: Public Health Reform in the Ottoman Empire and Egypt" (2003 Third Year Paper, Harvard Law School, 26 April 2003) (Erişim 2 Şubat 2019).

Arıkan, Zeki: "Midilli-İstanbul Arasında Zeytinyağı Ticareti”, Ankara Üniversitesi Dil ve Tarih-Coğrafya Fakültesi Tarih Bölümü Tarih Araştırmaları Dergisi, 25/40 (2006), s. 1-28.

Atkins, Peter, Alessandro Stanziani: "From Laboratory Expertise to Litigation: The Municipal Laboratory of Paris and the London Inland Revenue Laboratory, 1870-1914. A Comparative Analysis", Christelle Rabier (ed.), Fields of Expertise: a Comparative History of Expert Procedures in Paris and London, 1600 to Present, Newcastle upon Tyne: Cambridge Scholars Publishing 2007, ss. 317-339.

Bach, O.: "The Testing of Olive Oil", The American Journal of Pharmacy, 55 (Temmuz 1883), s. 354-357.

Bakır, Abdülhalik: Ortaçă̆ İslam Dünyasında Itriyat, Gıda, İlaç Üretimi ve Tăgşişi, Ankara: Bizim Büro, 2000.

Carter, Oscar C. S.: "On the Detection of Adulterations in Oils", Proceedings of the American Philosophical Society, 22/120, Part IV (Ekim 1885), s. 296-299.

Doğan, Faruk: “Osmanlı Devleti'nde Zeytinyağı (1800-1920)” (Yayımlanmamış Doktora Tezi), Marmara Üniversitesi, 2007.

Dölen, Emre: “1870’li Yıllarda Mekteb-i Tıbbiye Laboratuvarında Yapılan Analiz ve İncelemeler”, Marmara Üniversitesi Eczacılık Dergisi, 2 (1992), s. 145-159.

Düstur, 1. Tertip, 8. Cilt, Ankara: Başvekalet Devlet Matbaası 1943.

Eldem, Vedat: Osmanlı İmparatorluğu’nun İktisadi Şartları Hakkında Bir Tetkik, Ankara: TTK 1994.

Ergin, Osman N.: Mecelle-i Umur-ı Belediyye, cilt 6, İstanbul: İstanbul Büyükşehir Belediyesi Kültür İşleri Daire Başkanlığı Yayınları 1995.

Günergun, Feza: "Chemical Laboratories in Nineteenth-Century Istanbul: A Case-Study on the Laboratory of the Hamidiye Etfal Children's Hospital”, Marta C. Lourenço, Ana Carneiro (ed.), Spaces and Collections in the History of Science The Laboratorio Chimico Overture, Museum of Science of the University of Lisbon 2009, s. 91-101.

Günergun, Feza: "XIX. Yüzyılın İkinci Yarısında Osmanlı Kimyager-Eczacı Bonkowski Paşa (1841-1905)”, I. Türk Tip Tarihi Kongresi Kongreye Sunulan Bildiriler, Ankara: TTK 1992, s. 229-252. 
Günergun, Feza, Şeref Etker: “From Quinaquina to 'Quinine Law': A Bitter Chapter in the Westernization of Turkish Medicine", Osmanlı Bilimi Araştırmaları, XIV/2 (2013), s. 41-68.

Hierholzer, Vera: “The 'War Against Food Adulteration': Municipal Food Monitoring and Citizen Self-Help Associaitions in Germany, 1870s-1880s", Peter Atkins, Peter Lummel, Derek J. Oddy (ed.), Food and the City in Europe Since 1800, Aldershot: Ashgate Publishing 2007, s. 117-128.

Karal, Enver Ziya: Osmanl Tarihi VII. Cilt, Islahat Fermanı Devri (1861-1876), Ankara: TTK Basımevi 2003.

Kocacık, Eyüp Talha, Afife Mat: “İstanbul'da Zehirler ve Zehirlenme Vakaları (1846-1917)”, Osmanlı Bilimi Araştırmalar, XV/2 (2014), s. 21-38.

Kurmuş, Orhan: Emperyalizmin Türkiye’ye Girişi, İstanbul: Yordam Kitap 2007.

Kuzucu, Kemalettin: “Gazete Reklamlarına Göre Osmanlı'nın Son Asrında İstanbul'un Beslenme Hayatına Bakış", I. Türk Mutfak Kültürü Sempozyumu, 14-15 Ekim 2010-Bilecik, Bilecik: Bilecik Şeyh Edebali Üniversitesi Yayınları 2012, s. 425-460.

Kütükoğlu, Mübahat S.: Balta Limanina Giden Yol Osmanl-İngiliz İktisadi Münasebetleri (1580-1850), Ankara: Türk Tarih Kurumu 2013.

Lancet Reports of the International Congresses of Hygiene and Demography held from 1876 to 1889, London: Ballantyne, Hanson and Co. 1891.

Marie, Ch.: "The Adulteration of Olive Oil", The American Journal of Pharmacy, 55 (Temmuz 1883), s. 25-27.

Norton, Thomas H.: "Cotton Oil in Turkey", Levant Trade Review, 5/4 (March Quarter 1916), s. 328-334.

Oddy, Derek J.: "Food Quality in London and the Rise of Public Analyst, 1870-1939”, Peter Atkins, Peter Lummel, Derek J. Oddy (ed.), Food and the City in Europe Since 1800, Aldershot: Ashgate Publishing 2007, s. 91-103.

Oddy, Derek J.: “Introduction”, Derek J. Oddy, Alain Drouard (ed.), The Food Industries of Europe in the Nineteenth and Twentieth Centuries, New York: Routledge 2016, s. 1-16.

Pamuk, Şevket: 19. Yüzyılda Osmanlı Dış Ticareti Tarihi İstatistikler Dizisi Cilt 1, Ankara: T.C. Başbakanlık Devlet İstatistik Enstitüsü 1995.

Pamuk, Şevket: Osmanlı Ekonomisinde Băğmlılık ve Büyüme 1820-1913, İstanbul: Tarih Vakfi Yurt Yayınları 2005.

Phillips, Jim, Michael French: "Adulteration and Food Law, 1899-1939", Twentieth Century British History, 9/3 (1998), s. 350-369.

Ramon-Muñoz, Ramon: “Modernizing the Mediterranean Olive-Oil Industry, 1850s-1930s", Derek J. Oddy, Alain Drouard (ed.), The Food Industries of Europe in the Nineteenth and Twentieth Centuries, New York: Routledge 2016, s. 71-88. 
Ramon-Muñoz, Ramon: "Specialization in the International Market for Olive Oil Before World War II”, Şevket Pamuk ve Jeffrey G. Williamson (ed.), The Mediterranean Response to Globalization before 1950, London: Routledge 2000, s. 159-198.

Ransom, Luther A.: The Great Cottonseed Industry of the South, New York: Oil, Paint and Drug Reporter 1911.

Report of the Commissioner of Internal Revenue for the Fiscal Year Ended June 30, 1888, Washington: Government Printing Office 1888. (https://babel.hathitrust.org/cgi/pt ?id=njp.32101067873743;view=1 up;seq=9;size=125) (Erişim 31 Ocak 2018)

Richards, Edgar: "Legislation of Food Adulteration”, Science, 16/394 (Aug. 22, 1890), s. 101-104.

Sadtler, Samuel P.: A Handbook of Industrial Organic Chemistry, Philadelphia: J.B. Lippincott Company 1892.

Sağlam, Tevfik: Nasıl Okudum, İstanbul: İstanbul Matbaası 1981.

Samancı, Özge: “Avrupa'da ve Türkiye’de Yemek Tarihçiliğine Kısa Bir Bakış”, Ayşegül Avc1, Seda Erkoç, Elvin Otman (haz.), Yemekte Tarih Var Yemek Kültürü ve Tarihçiliği, İstanbul: Tarih Vakfi Yurt Yayınları, 2012, s. 27-40.

Sarıçelik, Kerim: “Osmanlı Dönemi’nde Isparta ve Burdur Sancaklarında Gülcülük ve 1913 Tarihli Gül Yağlarının Men-i Tağşişi Talimatnamesi”, SDÜ Fen Edebiyat Fakültesi Sosyal Bilimler Dergisi, 38 (Ağustos, 2016), s. 37-50.

Scholliers, Peter: "Food Fraud and the Big City: Brussels' Response to Food Anxieties in the 19th Century", Peter Atkins, Peter Lummel, Derek J. Oddy (ed.), Food and the City in Europe Since 1800, Aldershot: Ashgate Publishing 2007, s. 77-90.

Shaw, Stanford J.: “The Nineteenth-Century Ottoman Tax Reforms and Revenue System”, International Journal of Middle East Studies, 6/4 (1975), s. 421-459.

Shillington, Jessie: "History of National Pure Food and Drug Legislation in the United States to 1906" (Yayımlanmamış Master Tezi), University of Kansas, 1915.

Sifneos, Evridiki: "On Entrepreneurs and Entrepreneurship of the Olive-Oil Economy in the Aegean: The Case of Lesvos Island”, The Historical Review, I (2004), s. 245-273.

Stanziani, Alessandro: "Municipal Laboratories and the Analysis of Foodstuffs in France under the Third Republic: A Case Study of the Paris Municipal Laboratory, 18781907”, Peter Atkins, Peter Lummel, Derek J. Oddy (ed.), Food and the City in Europe Since 1800, Aldershot: Ashgate Publishing 2007, s. 105-115.

Şiviloğlu, Murat Remzi: "The Emergence of Public Opinion in the Ottoman Empire (1826-1876)” (Yayımlanmamış Doktora Tezi), University of Cambridge, 2014.

Thurston, Azor: Pharmaceutical and Food Analysis, New York: D. Van Nostrand Company 1922. 
Tolman, L. M., L. S. Munson: Olive Oil and Its Substitutes, Washington: Government Printing Office 1903.

Ünver, Metin: "Midilli Adası'nın İdari ve Sosyo-Ekonomik Yapısı (1876-1914)" (Yayımlanmamış Doktora Tezi), İstanbul Üniversitesi, 2012.

Yenson, Mutahhar: "19. Yüzyıl Tipsal Kimya Laboratuarcılığımızın Tip Tarihimiz Bakımından Önemi”, I. Türk Tip Tarihi Kongresi Kongreye Sunulan Bildiriler, Ankara: TTK 1992, s. 137-139.

Yıldırım, Nuran: "İstanbul Eczanelerinde Hasta Muayenesi ve Tibbi Tahlil Laboratuvarları", Yeni Tip Tarihi Araştırmaları, 2-3 (1996/97), s. 71-97.

Yıldırım, Nuran: "Osmanlı Devleti'nde Gıda Kontrolüne Bakış", 14. Yüzylldan Cumburiyete Hastalıklar-Hastaneler-Kurumlar Sağlık Tarihi Yazıları I, İstanbul: Tarih Vakfı Yurt Yayınları 2014, s. 54-69. 
